Journal of Advanced Research in Fluid Mechanics and Thermal Sciences

Journal homepage: www.akademiabaru.com/arfmts.html ISSN: 2289-7879

\title{
Designing of Underground Coal Gasification Unit
}

\author{
Rizwan Ahmed Qamar ${ }^{1}$, Asim Mushtaq ${ }^{2, *}$, Ahmed Ullah' ${ }^{1}$, Zaeem Uddin Ali $^{1}$ \\ Chemical Engineering Department, NED University of Engineering \& Technology, Karachi, Sindh, Pakistan \\ Polymer and Petrochemical Engineering Department, NED University of Engineering \& Technology, Karachi, Sindh, Pakistan
}

\section{ARTICLE INFO}

\section{Article history:}

Received 7 February 2020

Received in revised form 20 March 2020

Accepted 22 March 2020

Available online 27 May 2020

\section{ABSTRACT}

Pakistan is one of the biggest country for coal reserves in the world. Those coal reserves if exploited, will help in fulfilling the growing need of Pakistan's energy sector. The ultimate goal for "Underground Coal Gasification" is to design a new system that can produce sufficient electricity and is relatively cleaner and environment-friendly. The coal reserves that are unfeasible to mine may be utilized by UCG technology. The process can be categorized according to the material injected air-steam injection, oxygen-steam injection. Both categories have their advantages and drawbacks and the process oxygen-steam injection was selected as being more economical. The project being relatively new is still in an experimental and research stage. Thus, the approach of the research throughout is experimental. In this research, formed several models using software like MathCAD and MS Excel that might be useful for further researchers and designers to improve the process.

Keywords:

Coal; gasification unit; oxygen;

MathCAD; energy

Copyright @ 2020 PENERBIT AKADEMIA BARU - All rights reserved

\section{Introduction}

The recently there came a report in the leading newspapers that Pakistan is rich in coal deposits and we should use it for the generation of electricity but another leading factor that people are overlooking is that the gas reserves in the country are depleting and that there would be no alternative to it. The fertilizer industry is a major user of the natural gas. So, we thought that if we could provide an alternative source of energy through coal, it would be very beneficial for our country as there are vast coal reserves in Pakistan. When the nation is confronting a vitality shortage of thousands of megawatts and power blackouts have injured each circle of life, one would have believed that the government would burn through no time in abusing the Thar coal reserves [1-2].

As indicated by atomic researcher, the coal stores can empower the nation to create $50,000 \mathrm{MW}$ for a long time. It involves incredible worry that despite what might be expected, personal stakes are attempting to obstruct the venture. Happening in rock strata in layers or veins called coal creases or

\footnotetext{
* Corresponding author.

E-mail address: engrasimmushtaq@yahoo.com (Asim Mushtaq)
}

https://doi.org/10.37934/arfmts.71.2.103133 
coal beds. The harder structures, like, anthracite coal, can be observed as transformative stone due to later introduction to raised temperature and weight. Coal is made basically out of carbon along with factor amounts of various components, essentially sulfur, oxygen, hydrogen and nitrogen. The formation of coal is shown in Figure 1 [3-4]. As plants and trees decay, their remaining parts sank to the base of the territories, gathering layer upon layer and in the long run shaping a thick, saturated material known as peat [5-6]. The weight from overlying dregs that cover a peat bed will minimal the coal. Peats change to second rate lignite once they are packed to about $20 \%$ of their unique thickness. Lignite commonly changes to bituminous coal as it is packed further and warmed to somewhere in the range of 100 and $200^{\circ} \mathrm{C}$. This efforts a great part of the water and different volatiles from the coal. Longer presentation to raised temperature will additionally drive volatiles from the coal, and drive synthetic responses that produce Anthracite. Anthracite coals are normally packed to $5-10 \%$ of the first thickness of the peat bed, and comprise $10 \%$ water and different volatiles. Coal is frequently found in beds around a meter or more in thickness that are far reaching in degree. These are regularly extracted to extricate the coal for use as a non-renewable energy source [7-8].

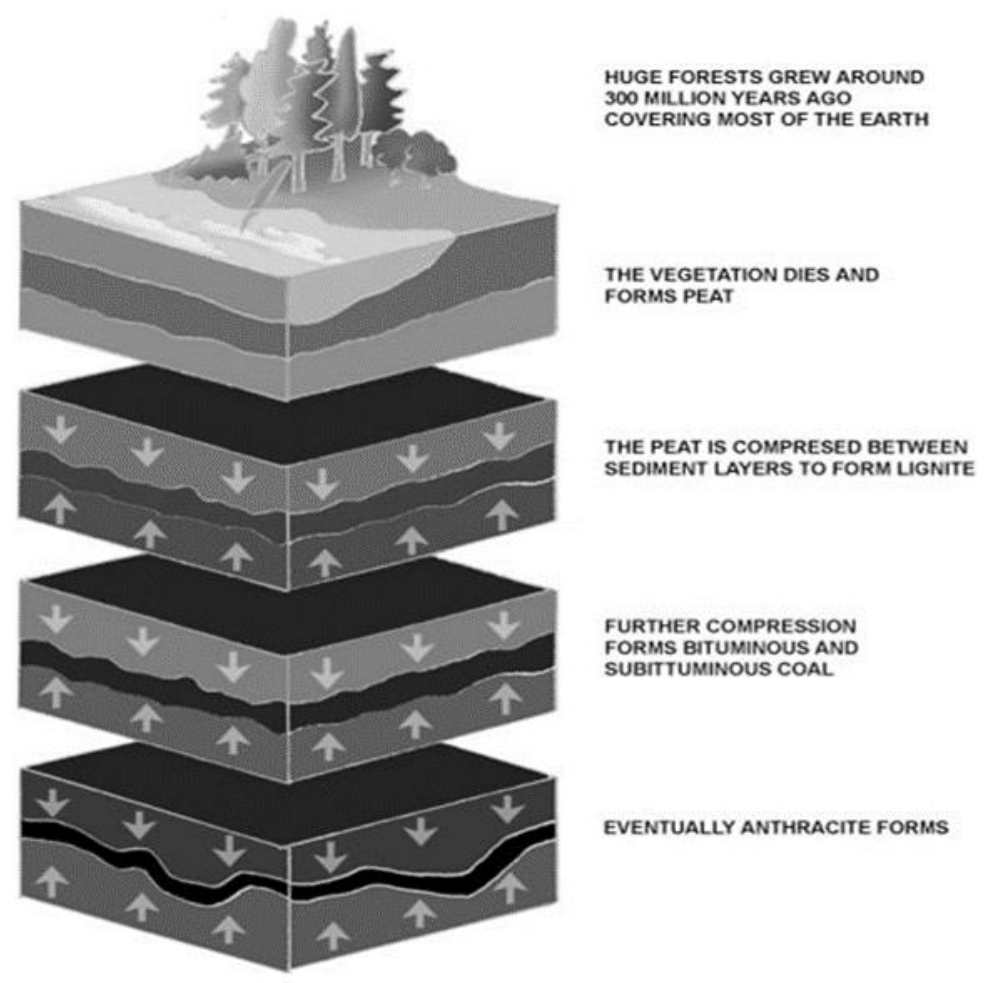

Fig. 1. Coal formation

In-situ gasification strategies have not been effective so far as business usage methods. Over $60 \%$ of coal creation, when all is said in done around the world, is devoured for making of electric force while $25 \%$ is utilized for the production of metallurgical coke. Productions containing concrete and paper factories, synthetic plants, household and other warming establishments [6,9].

In spite of the fact that coal has enrolled a slight interfered with as a wellspring of vitality because of expanded portion of natural gas, petroleum products, atomic force and sun based/wind vitality still it keeps on being a key source of vitality uncommonly for power generation. Concrete and force plants are progressively being changed over to coal around the world. Now, the portion of coal in world power utilization is about $38 \%$. This projection represents $33 \%$ of the world's absolute increment in vitality utilization and $90 \%$ of world's complete increment in coal use. Pakistan's offer in it has still to be resolved. Coal is a cheap indigenous vitality asset and, after the revelation of 175.5 
billion tons of coal in Thar zone, Pakistan's coal potential power has expanded complex. It is foreseen that, if appropriately exploited, coal assets may create over 100,000 MW of power for the following 30 years in Pakistan [9-10]. There are immense assets of coal in each of the four provinces of Pakistan and in Azad Kashmir. As per harsh appraisals, the absolute coal stores are more than 185 billion tons. Coal holds with warming qualities are given in Table 1 and qualities of coal present in Pakistan are present in Table 2 [5, 11-12].

Table 1

Coal resources and its heating values

\begin{tabular}{lll}
\hline Province & Resources in Million Tones & Heating value (Btu/lb) \\
\hline Sindh & 184623 & $5219-13555$ \\
Punjab & 235 & $9472-15801$ \\
Baluchistan & 217 & $9637-15499$ \\
NWFP & 91 & $9386-14217$ \\
AJK & 9 & $7336-12338$ \\
Total & 185175 & \\
\hline
\end{tabular}

Table 2

Qualities of coal present in Pakistan

\begin{tabular}{|c|c|c|c|c|c|}
\hline & $\begin{array}{l}\text { Sindh } \\
\text { (Thar) }\end{array}$ & $\begin{array}{l}\text { Balochistan } \\
\text { (Sor-Range and } \\
\text { Degari Coal) }\end{array}$ & $\begin{array}{l}\text { Punjab } \\
\text { (Sargodha and } \\
\text { Jhelum) }\end{array}$ & $\begin{array}{l}\text { NWFP (Hangu } \\
\text { and Cherat) }\end{array}$ & AJK \\
\hline Moisture (\%) & $29.60-55.50$ & $3.90-18.90$ & $3.20-10.80$ & $0.10-7.10$ & $0.20-6.00$ \\
\hline Ash content (\%) & $2.90-11.50$ & $4.90-17.20$ & $12.30-44.20$ & $5.30-43.30$ & $3.30-50.00$ \\
\hline $\begin{array}{l}\text { Volatile matter } \\
(\%)\end{array}$ & $23.10-36.60$ & $20.70-37.50$ & $21.50-38.80$ & $14.00-33.40$ & $5.10-32.00$ \\
\hline Fixed carbon (\%) & $14.20-34.00$ & $41.00-50.80$ & $25.70-44.80$ & $21.80-76.90$ & $26.30-69.50$ \\
\hline Sulfur (\%) & $0.40-2.90$ & $0.60-5.50$ & $2.60-10.70$ & $1.10-9.50$ & $0.30-4.80$ \\
\hline $\begin{array}{l}\text { Heating value } \\
\text { (Btu/lb) }\end{array}$ & $10723-11353$ & $11245-13900$ & $9472-15801$ & $9386-14217$ & $7336-12338$ \\
\hline Quality of coal & $\begin{array}{l}\text { Lignite } B \text { to } \\
\text { Lignite } A\end{array}$ & $\begin{array}{l}\text { Sub-bituminous } \\
\text { to bituminous }\end{array}$ & Sub-bituminous & Sub-bituminous & $\begin{array}{l}\text { Sub- } \\
\text { bituminous }\end{array}$ \\
\hline \multicolumn{6}{|l|}{$\begin{array}{l}\text { Quantity (Million } \\
\text { Tones) }\end{array}$} \\
\hline $\begin{array}{l}\text { Measured } \\
\text { Indicated }\end{array}$ & 2700 & 15 & 50 & 2 & 1 \\
\hline Inferred & 9395 & 16 & 16 & 5 & 1 \\
\hline Hypothetical & $\begin{array}{l}50706 \\
112705\end{array}$ & 19 & 147 & 84 & 7 \\
\hline Total & 175506 & 50 & 213 & 91 & 9 \\
\hline $\begin{array}{l}\text { Thickness of coal } \\
\text { bed }(m)\end{array}$ & $0.2-22.8$ & $0.3-2.3$ & $0.3-1.5$ & 3.5 & 0.6 \\
\hline
\end{tabular}

Figure 2 shows the chemical structure of coal. Kinds of coals incorporate peat, lignite, bituminous, sub-bituminous, anthracite, steam and graphite. Peat is viewed as a forerunner of coal. In its driedout structure, peat is a profoundly successful permeable for oil and fuel slicks ashore and water. Lignite, additionally alluded to as darker coal, is the most reduced position of coal and utilized only as fuel for electric force age. Sub-bituminous coal properties extend from lignite to bituminous coal, are utilized principally as fuel for steam-electric power generation. Also, it is a significant wellspring of light sweet-smelling hydrocarbons for the synthetic combination industry. Bituminous coal, thick sedimentary stone, dark however some of the time dim darker, frequently with well-characterized groups of splendid and dull material, utilized principally as fuel in steam electric power generation, 
with considerable amounts likewise utilized for force and heat usages in assembling and to make coke. Steam coal is an evaluation concerning bituminous and anthracite coal, when broadly utilized as a fuel for steam trains. Anthracite, the most elevated position; lustrous, a harder, dark coal utilized basically for business and private space warming. Graphite, in fact the most noteworthy position, however hard to touch off and isn't so regularly utilized as fuel: it is for the most part utilized in pencils and, when powdered, as an oil [13-14].

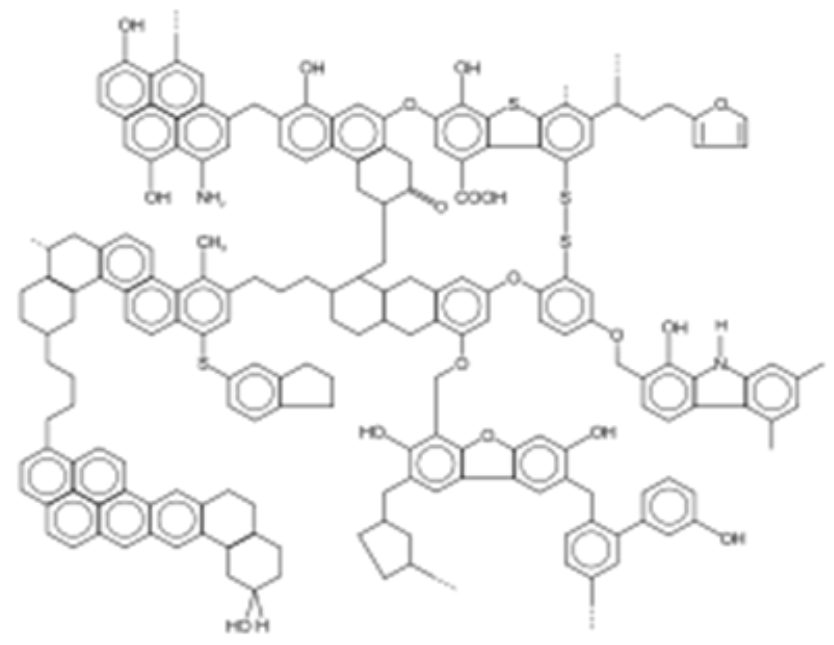

Fig. 2. Chemical structure of coal

This classification shows the transition stages of coal from lignite to anthracite. The center 6 grades coal in the Table 3 present a dynamic progress from the sub-bituminous coal to bituminous coal. A more vitality proficient method for utilizing coal for power generation would be by means of strong oxide energy components or liquid carbonate power devices (or any oxygen particle transport based energy units that don't separate among fuels, if they devour oxygen), that would have the option to get $60 \%$ to $85 \%$ joined effectiveness (direct power + squander heat turbine). As of now these fuel cell innovations can just make gaseous fuels, and delicate to sulfur harming, issues that initially turned out before enormous business achievement conceivable with coal [15-16].

Table 3

Classification of coal by weight percent

\begin{tabular}{lllllll}
\hline Name & Volatiles \% & Carbon \% & Hydrogen \% & Oxygen \% & Sulfur \% & Heat content kJ/kg \\
\hline Lignite & $45-65$ & $60-75$ & $6.0-5.8$ & $34-17$ & $0.5-3$ & $<28470$ \\
Gas flame coal & $35-40$ & $82-85$ & $5.8-5.6$ & $9.8-7.3$ & $\sim 1$ & $<33910$ \\
Gas coal & $28-35$ & $85-87.5$ & $5.6-5.0$ & $7.3-4.5$ & $\sim 1$ & $<34960$ \\
Flame coal & $40-45$ & $75-82$ & $6.0-5.8$ & $>9.8$ & $\sim 1$ & $<32870$ \\
Forge coal & $14-19$ & $89.5-90.5$ & $4.5-4.0$ & $3.2-2.8$ & $\sim 1$ & $<35380$ \\
Fat coal & $19-28$ & $87.5-89.5$ & $5.0-4.5$ & $4.5-3.2$ & $\sim 1$ & $<35380$ \\
Non baking coal & $10-14$ & $90.5-91.5$ & $4.0-3.75$ & $2.8-3.5$ & $\sim 1$ & 35380 \\
Anthracite & $7-12$ & $>91.5$ & $<3.75$ & $<2.5$ & $\sim 1$ & $<35300$ \\
\hline
\end{tabular}

Coal gasification can be utilized to deliver syngas, a combination of hydrogen $\left(\mathrm{H}_{2}\right)$ and carbon monoxide (CO) gas. This syngas would then be able to be changed over into transportation fills like gas and diesel by Fischer-Tropsch process. On the other hand, the hydrogen acquired from gasification can be utilized for different purposes, for example, driving a hydrogen economy, redesigning non-renewable energy sources or making ammonia. In gasification, the coal is mix with oxygen and steam however additionally being warmed and pressurized. Throughout the reaction, 
water and oxygen particles oxidize the coal into $\mathrm{CO}$ and discharging $\mathrm{H}_{2}$ gas. This procedure has been directed in underground coal mineshafts and in coal processing plants $[8,16]$. Coal was changed over to produce coal gas, was supplied to consumers to consume for light, warming, and cooking.

Coal $+\mathrm{H}_{2} \mathrm{O}+\mathrm{O}_{2} \rightarrow \mathrm{CO}+\mathrm{H}_{2}$

Coal liquefaction techniques include $\mathrm{CO}_{2}$ discharges in the conversion procedure. If coal liquefaction is managed without utilizing carbon catch and storage innovations or biomass mixing, the outcome is lifecycle ozone depleting substance impressions that are commonly more significant than those discharged in the extraction and refinement of fluid fuel creation from crude oil. For future research, $\mathrm{CO}_{2}$ sequestration is proposed to abstain from discharging it into the environment and add to the expense of production.

Underground Coal Gasification (UCG) is the procedure in which coal is changed over in situ into a combustible gas that can be utilized as a chemical feedstock or fuel. It is a procedure to change over unmixable underground coal into flammable gases (ignitable syngas) by gasifying. UCG utilizes a comparative procedure to surface gasification. As a strategy for exploiting coal, UCG signifies natural enhancement for the mix of surface combustion of coal and coal mining. It is additionally more secure and effective $[5,17]$. The essential UCG process includes boring two wells into the coal, first for infusion of the oxidants (water/oxygen blends) and other well for some separation away to get the product to the surface. Coal is gasified below the ground by making a connection by the coal seam amid the infusion and production wells and infusing water and air in the underground zone. The infused gases respond with coal to shape a combustible gas that transported to the surface of production well, cleaned and utilized as a fuel or substance feedstock. A cavity is shaped as the coal consumes and the rooftop breakdown. This outcome in horizontal development and is permitted to proceed till the gas quality of product disintegrates. The more prominent the sidelong development, the more drawn out the life of a gasifier and the will be more economical. At the point when the product gas quality decreases, crisp coal is touched off more along the infusion well. When the coal inside the earth gasifier has been depleted, new infusion and creation wells are bored and the procedure is rehashed $[1,5]$.

Infusing $\mathrm{O}_{2}$ as opposed to air diminishes the $\mathrm{N}_{2}$ substance and increases the heating rate of the delivered gas to the 'medium-Btu' gas range is around one-fourth of petroleum gas. If the objective is high-Btu gas (SNG), the level of $\mathrm{CH}_{4}$ in the formed gases should be supported. For $\mathrm{CH}_{4}$ development in UCG, two extra advances are requisite. In the first place, a portion of the CO produce in the gasification procedure is responded with steam to frame extra $\mathrm{H}_{2}$. This progression, termed as move change, sets up the best possible proportion of gases for the following stage known as methanation. The hot gas in this manner created is permitted to go through the coal crease to the leave boreholes and is conveyed to the surface from where it is overhauled and cleaned for use.

The gasification contrasts from combustion, happens when coal is scorched in overabundance oxygen to create $\mathrm{CO}_{2}$ and $\mathrm{H}_{2} \mathrm{O}$. One more significant distinction among coal burning and coal gasification is in toxin development. The decreasing air in gasification changes over $\mathrm{S}$ from $\mathrm{N}$ to $\mathrm{NH}_{3}$ and coal to $\mathrm{H}_{2} \mathrm{~S}$, while oxidation built sulfur dioxide and oxides of $\mathrm{N}_{2}$. The principle gases created are $\mathrm{CO}_{2}, \mathrm{H}_{2}, \mathrm{CH}_{4}$ and $\mathrm{CO}$ and $\mathrm{O}_{2} . \mathrm{CH}_{4}$ is basically a result of pyrolysis, instead of gasification. Its development is supported by high pressure and low temperature $[2,18]$.

In a hypothetical examination of the gasification procedure, the Autothermal Chemical Equilibrium (ACE) condition exists. In this condition the conversion proficiency of the gasified coal and heat estimation of the product gas (concoction vitality of item gas/synthetic vitality of gasified coal) is a greatest. At high pressures and temperatures (state $5 \mathrm{MPa}, 900^{\circ} \mathrm{C}$ ), ACE conditions are drawn 
nearer quickly however at lower temperatures and constrains an opportunity to accomplish equilibrium significantly surpass the residence of the gases in the gasifier and subsequently ACE won't be achieved $[11,19]$. The essential reactions can be summed up to a basic empirical structure:

$$
\begin{aligned}
& \mathrm{C}+\mathrm{O}_{2} \rightarrow \mathrm{CO}_{2} \text { (+heat) } \\
& \mathrm{C}+\mathrm{CO}_{2} \text { (+heat) } \rightarrow 2 \mathrm{CO} \\
& \mathrm{C}+\mathrm{H}_{2} \mathrm{O} \text { (+heat) } \rightarrow \mathrm{H}_{2}+\mathrm{CO} \\
& \mathrm{C}+2 \mathrm{H}_{2} \rightarrow \mathrm{CH}_{4} \text { (+heat) }
\end{aligned}
$$

The gasification circuit involves a stream connect to be accomplished between a production well and infusion. Establishment of well combines both exorbitant and hence it is alluring to gasify the most extreme volume of coal amongst a well pair. As gasification continues, a cavity is made that will stretch out till the roof collapses. This roof collapses is significant as it helps the sidelong development of the gasifier. Where the rooftop is solid and neglects to break, or gotten ground is blocky and ineffectively merged, some liquid reactants will pass by the coal and the effectiveness of the reactor could decrease quickly [20-21].

UCG can possibly exploit coal assets that are inefficient to work coal extraction by customary underground, or difficult to reach because of profundity, geography or other mining and security contemplations. The effective improvement of UCG won't just rely upon progresses in the utilization of innovation yet in addition on exhibiting that a perfect vitality can be created without hindrance to the earth. As a strategy to take advantage of coal, UCG speaks to a considerable natural enhancement for the mix of surface combustion of coal and coal mining. At the surface the syngas is changed over to $\mathrm{CH}_{4}$ and afterward Dimethyl Ether (DME), whenever required, in a little synthetic plant or for some further use $[7,21]$.

\section{Methodology}

\subsection{Process Description}

Figure 3 represents the process flow diagram. This process was chosen for the following reasons. More cooling of syngas is achieved. The energy utilization of air blowing fan is very large as compared to the open and closed-circuit cooling systems. More cyclones mean bypass can be possible and no need to shut down the system for maintenance. UCG is at experimental stage throughout the world. Few countries like Russia, China and Australia are producing significant amount of syngas through UCG process. Other countries such as US, India and few parts of Europe, as well as in Pakistan, UCG is still in the experimental phase [14, 21].

UCG process involves several steps such as site preparation, injection of reactants, gasification (drying, pyrolysis, and oxidation), purification of coal gas (solid-gas saperation, syngas cooling, scrubbing, demin water cooling) and utilities (boiler, cooling tower). Steam at $573 \mathrm{~K}$ and oxygen at $313 \mathrm{~K}$ are injected into the bore hole. Valves are used to maintain pressure at 34 barg and 35 barg and flowrate at $1343 \mathrm{~kg} / \mathrm{hr}$ and $7123.4 \mathrm{~kg} / \mathrm{hr}$ of steam and oxygen respectively in the rigs and inside the gasifier well. The steam and oxygen reach the coal seam with same drop in temperature and pressure. There the coal reacts with the incoming feed to form different products. The temperature and pressure inside the gasifier vary throughout the different stages of the gasifier. The process gasification initiates with the drying step as soon as the temperature in the gasifier reaches $373 \mathrm{~K}$ or 
above. Liquid water leaves the particles in the form of steam. The drying of water in the coal particles are governed by the normal law of drying, which takes place in several stages as explained in the Figure 4 [21-22].

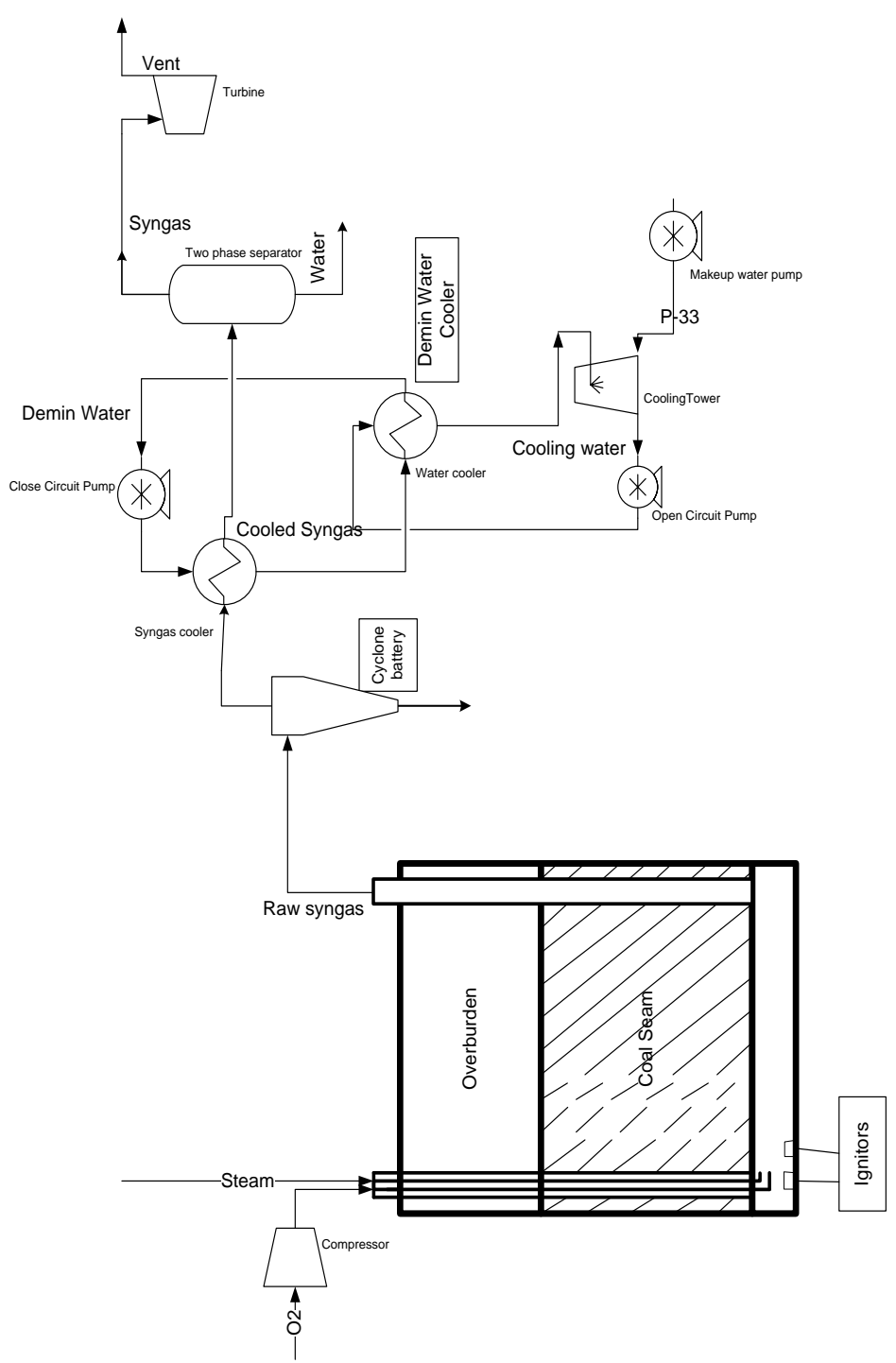

Fig. 3. The process flow diagram

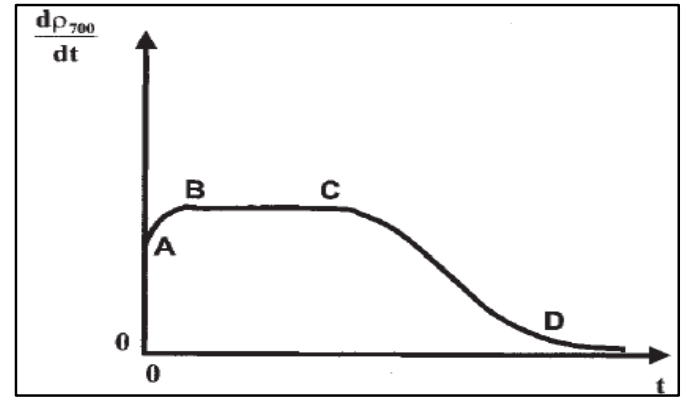

Fig. 4. Typical drying rate as function of time for a porous particle

In Figure 4, A to B shows heating of porous coal molecule. In the event that the temperature of the combustion gas around the coal molecule is equivalent to or over the boiling point of water at 
pressure of atmosphere around the molecule, the fluid water at molecule surface watches out for saturation temperature. In the event that the gas temperature around the coal particle is less than the boiling temperature of water on surface to particle at pressure of atmosphere, the fluid water at surface will in general wet bulb temperature registered from gas blend close to the surface. From $B$ to $C$ speaks to consistent drying rate region. The liquid is stored in interior pores of coal molecule and they continuously reach the surface of coal particle forming thin film of water on surface of coal. The water evaporates into combustion gas around the particle lays on the surface remain wet and surrounding conditions remain same, the rate of drying will be consistent. From C to D; in this region, the surface of coal particle is no longer wet the liquid water in inner pores changes to steam. Steam needs to go through a layer of dried coal.

Pyrolysis is known devolatilization or warm disintegration, ascarbonisation and gasification. Throughout pyrolysis coal is changed over to a roast discharging tars, oils, low atomic hydrocarbons and different gases. The gasification happens when $\mathrm{H}_{2} \mathrm{O}, \mathrm{O}_{2}, \mathrm{CO}_{2}$ and $\mathrm{H}_{2}$ respond with the scorch. The primary gases created are $\mathrm{CO}_{2}, \mathrm{CH}_{4}, \mathrm{H}_{2}$ and $\mathrm{CO}$. The $\mathrm{O}_{2}$ and $\mathrm{CH}_{4}$ is basically a result of pyrolysis, as opposed to gasification.

Oxidation is a process in which oxygen, steam, carbon dioxide and hydrogen react with char. The resulting gas is known as raw syngas which returns to surface via production bore well and is sent to the purification plant. The coal gas obtained from gasifier needs to be further processed in order to utilize it commercially. The following steps are involved in purifying the coal gas.

\subsubsection{Solid-gas separation}

The coal gas contains significant amount of dust and solid particles in it that could cause fouling in the equipment. A cyclone separator is used to remove the solid particles from the gas.

\subsubsection{Syngas cooling}

Syngas flows in the tubes of two-phase heat exchanger. It enters at $500 \mathrm{~K}$ temperature and 34 barg pressure and is cooled to $373 \mathrm{~K}$ and 33.5 barg pressure. Demineralized water is used in the shell and it gets heated from $323.1 \mathrm{~K}$ to $333.1 \mathrm{~K}$.

\subsubsection{Two phase separator}

Vertical separators are normally chosen when the vapor/liquid proportion is high or total volume is low. A vertical separator consumes less floor space than a horizontal separator and is regularly viewed as when plot space is restricted. In any case, a vertical separator might be bigger and more costly than a horizontal separator for similar gas taking care of limit because of the upward progression of gas impeding the falling liquid droplets. In the vertical separator, the liquids go into the vessel striking distracting baffle which starts essential separation. Fluid expelled by the inlet baffle to the base of the vessel. The gas goes upward, generally going over a mist extractor or "demister pad" to expel suspended mist. Fluid expelled by the demister pad is combine into bigger droplets which at that point fall through the gas to the fluid source in the base. The capacity to deal with fluid slugs is normally acquired by expanding stature. Level control isn't basic and the level of fluid can fluctuate few inches without influencing operational effectiveness. Mist extractors can fundamentally decrease the necessary width of vertical separators. 


\subsubsection{Demineralized water cooling}

Hot demineralized water at $333.1 \mathrm{~K}$ is chilled off to $323.1 \mathrm{~K}$ by utilizing a shell and cylinder heat exchanger. The demineralized water is coursed through the shell and the cold tap water is streamed in tubes. This demineralized water is sent back to the syngas cooler to frame a cyclic procedure. Following utilities are utilized in underground coal gasification (UCG) plant.

\subsubsection{Boiler}

This is utilized to create steam at required temperature and pressure for the infusion in the gasifier of UCG plant. The item syngas is utilized a fuel in evaporator. The two essential setups of mechanical boilers are; Fire Tube Boilers and Water Tube Boiler. As the necessary pressure of steam is high and water tube boilers can be projected to misuse any heat source and are generally favored in high pressure applications as the high pressure water/steam is contained inside measurement pipes, subsequently a Water Tube Boiler is utilized to change over water into steam. The water tube heater courses water inside cylinders and warms the cylinders remotely by the fire. Subsequently at the outlet a high pressure steam is accessible for the infusion into the gasifier.

\subsubsection{Cooling tower}

In the Cooling tower the warm water from the warmth exchanger is cooled by reaching it with surrounding air. The warm water is siphoned to the highest point of the IPCT (mechanical procedure cooling tower) and is disseminated over the distribution deck where it moves through a series of nozzles onto the highest point of the tower's fill material. A small percentage of the water dissipates, cooling the flowing water and warming the air. The warm, clammy air at that point goes through the float eliminator and ways out the pinnacle through the fan stack(s), completing some leftover float of the tower. The cooled water falls into a virus water bowl, which is at the base of the IPCT. From that point, the water exposed to the harsh elements water bowl is siphoned back to the heat exchanger for additional cooling purposes. The developed different models of UCG considering different constraints and assumptions. On the basis of these assumptions we have the following steady state models: GIBB's free energy model, kinetic model with reversibility, kinetic model (irreversible and no sulphur) and kinetic model (irreversible and sulphur included).

\subsection{Gibb's Free Energy Model}

In this model, Gibb's Free Energy was used to calculate simultaneous heat and mass balance. Firstly, a property data was developed which includes entropy, enthalpy, Gibb's energy, heat capacity of different Hydrocarbons ranging from elemental carbon to heavier $\mathrm{C}_{6} \mathrm{H}_{14}$, moreover some inorganic compounds like Oxygen, Sulfur and Nitrogen were also included. Coal data from Thar Block III-A was used for the calculations. The composition of the specified coal is shown in the Table 4.

$G(p, T)=H-T S$

Table 4

Composition of the specified coal

\begin{tabular}{|l|l|l|l|l|l|l|}
\hline Fixed Carbon & Ash & Hydrogen & Carbon & Nitrogen & Sulfur & Calorific Value \\
\hline 40.76 & 5.36 & 6.59 & 61.84 & 0.33 & 0.99 & 10190 \\
\hline
\end{tabular}


The significant reactions occurring inside the gasifier are considered for the calculations of minimum Gibb's free energy. These reactions will attain equilibrium when the Gibb's free energy of the control system is minimum $[20,23]$.

Reaction 1: Water Gas Shift Reaction

$\mathrm{CO}+\mathrm{H}_{2} \mathrm{O} \longrightarrow \mathrm{CO}_{2}+\mathrm{H}_{2}$

Reaction 2: $\mathrm{CO}_{2}$ Reforming

$\mathrm{CO}_{2}+\mathrm{CH}_{4} \longrightarrow 2 \mathrm{CO}+2 \mathrm{H}_{2}$

Reaction 3: $\mathrm{H}_{2} \mathrm{O}$ Reforming

$\mathrm{H}_{2} \mathrm{O}+\mathrm{CH}_{4} \longrightarrow \mathrm{CO}+3 \mathrm{H}_{2}$

Reaction 4: Boudouard Reaction

$2 \mathrm{CO} \longrightarrow \mathrm{CO}_{2}+\mathrm{C}$

Reaction 5: Beggs Reaction

$\mathrm{CO}+\mathrm{H}_{2} \longrightarrow \mathrm{C}+\mathrm{H}_{2} \mathrm{O}$

Reaction 6: Methane Cracking

$\mathrm{CH}_{4} \longrightarrow \mathrm{C}+2 \mathrm{H}_{2}$

Solving all the above equations simultaneously will yield the composition of the product gas.

\subsection{Kinetic Model with Reversibility}

Here reactions are considered to be reversible in nature i.e. they proceed in the forward direction as well as backward direction on changing the parameters inside the gasifier. The reactions that show significant reversibility will be considered. Based on the eight reactions simultaneous material and energy balance simulator was designed. Using this simulator a composition of product gas was calculated. The simulator was modeled by application of Runge-Kutta method $[8,23]$.

Runge-kutta equation

$$
\begin{aligned}
& y_{n+1}=y_{n}+\frac{1}{6}\left(k_{1}+2 k_{2}+2 k_{3}+k_{4}\right) \\
& t_{n+1}=t_{n}+h
\end{aligned}
$$


where $y_{n+1}$ is the RK4 approximation of $y\left(t_{n+1}\right)$, and

$k_{1}=h f\left(t_{n}, y_{n}\right)$

$k_{2}=h f\left(t_{n}+\frac{1}{2} h, y_{n}+\frac{1}{2} k_{1}\right)$

$k_{3}=h f\left(t_{n}+\frac{1}{2} h, y_{n}+\frac{1}{2} k_{2}\right)$

$k_{4}=h f\left(t_{n}+h, y_{n}+k_{3}\right)$

The composition of each element was determined over $1 \mathrm{~m}$ step size. Similarly temperature variation with respect to length was calculated for each step. All the compositions were summed to get the molar flow rate of the gas, the BTU value, molecular weight and mass flow rate were also calculated on every step.

Shape Factor $=\operatorname{Pi}\{(r+1) 2-r 2\} *$ density $*$ ghsv * effectivity

The composition of the product gas highly varied from the results of the research papers. Hence this consideration is not feasible. The following two assumptions are taken into account for simplicity. Amount of sulfur in coal bed is ignored and the reactions are considered to be irreversible. These assumptions were incorporated in the simulator and new composition of the product gas was obtained, which was almost similar to the results in the research papers. Sulfur was included in the above model and new gas composition was calculated. The amount of sulfur obtained was minute so amount of sulfur content in the product gas maybe safely neglected [24-25].

\section{Results}

\subsection{Material and Energy Balance}

Table 5 shows thermodynamic property data and syn-gas cooler is shown in Figure 5.

Table 5

Thermodynamic Property Data

\begin{tabular}{llllll}
\hline Species & A & Bx1000 & C & Dx10^-5 & Mole Fraction \\
\hline $\mathrm{O}_{2}$ & 3.639 & 0.593 & 0 & 0.04 & 0 \\
$\mathrm{H}_{2}$ & 3.249 & 0.422 & 0 & 0.083 & 0.032419119 \\
$\mathrm{H}_{2} \mathrm{O}$ & 3.47 & 1.45 & 0 & 0.121 & 0.095977349 \\
$\mathrm{CO}_{2}$ & 5.457 & 1.045 & 0 & -1.157 & 0.444780754 \\
$\mathrm{CO}$ & 3.376 & 0.557 & 0 & -0.031 & 0.426822777 \\
& 4.306 & 0.855 & 0.00 & -0.514 & \\
\hline
\end{tabular}

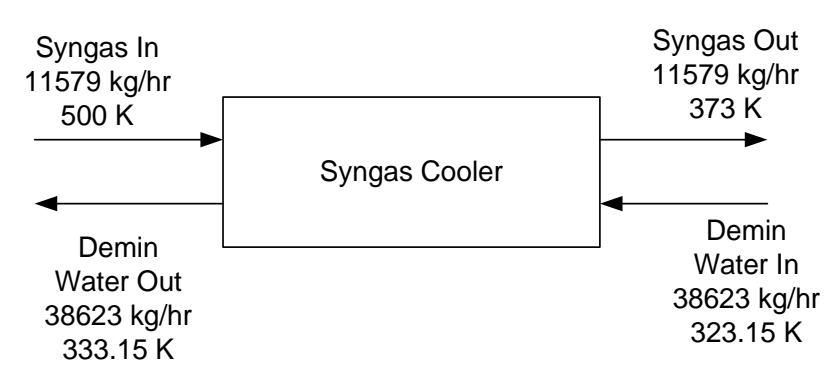

Fig. 5. Syn-gas cooler

Table 6 shows the gas flow rate for different gases. 


\section{Table 6}

Gas flow rate of different gases

\begin{tabular}{|l|l|l|l|l|l|l|}
\hline Species & $\mathrm{O}_{2}$ & $\mathrm{H}_{2}$ & $\mathrm{H}_{2} \mathrm{O}$ & $\mathrm{CO}_{2}$ & $\mathrm{CO}$ & Total \\
\hline Gas Flow $(\mathrm{kmol} / \mathrm{hr})$ & 0.00 & 11.26 & 33.35 & 154.55 & 148.31 & 347.48 \\
\hline
\end{tabular}

Hot Gas Temperature $=500$ or $\mathrm{K}=226.8^{\circ} \mathrm{C}$;

Cold Gas Temperature $=373 \mathrm{~K}$ or $99.85^{\circ} \mathrm{C}$;

Closed Circuit Cooling Water Supply Temperature $=333.15 \mathrm{~K}=60^{\circ} \mathrm{C}$;

Closed Circuit Cooling Water Return Temperature $=323.15 \mathrm{~K}\left(50^{\circ} \mathrm{C}\right)$;

Water Density $=1000 \mathrm{~kg} / \mathrm{m}^{3}=62.38 \mathrm{lb} / \mathrm{ft}^{3}$;

Syn Gas Cooler Duty $=1,615,991,272 \mathrm{~J} / \mathrm{hr}=448.9 \mathrm{~kW}$ or $1.5317 \mathrm{MMBTU} / \mathrm{hr}$ and

Closed Circuit CW Flow $=38623.1 \mathrm{~kg} / \mathrm{hr}$ or $38.62 \mathrm{~m}^{3} / \mathrm{hr}$.

Close circuit pump power

Figure 6 represents closed circuit water cooler. Differential Head=3bar, Flow $=38.62 \mathrm{~m}^{3} / \mathrm{hr}$, Efficiency $=55 \%$, Power $=3.22 \mathrm{~kW}$.

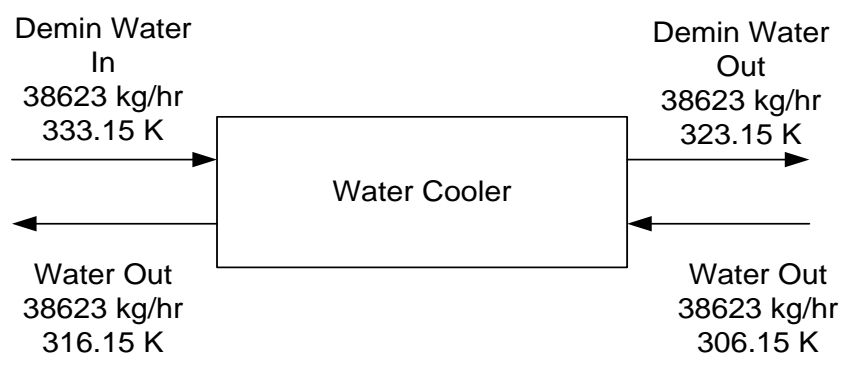

Fig. 6. Closed circuit water cooler

Closed Circuit Hot Water Temperature $=333.15 \mathrm{~K}=60^{\circ} \mathrm{C}$;

Closed Circuit Cold Water Temperature $=323.15 \mathrm{~K}=50^{\circ} \mathrm{C}$;

Open Circuit Cooling Water Supply Temperature $=306.15 \mathrm{~K}=33^{\circ} \mathrm{C}$;

Open Circuit Cooling Water Return Temperature $=316.15 \mathrm{~K}=43^{\circ} \mathrm{C}$;

Cooling Duty=1615991272 J/hr;

Open Circuit Cooling Water Flow $=38623.1 \mathrm{~kg} / \mathrm{hr}=38.62 \mathrm{~m}^{3} / \mathrm{hr}=85087.2 \mathrm{lb} / \mathrm{hr}=170.04 \mathrm{gpm}$

Cooling water pump power

Differential Head=6 bar=87 psi; Flow=38.62 $\mathrm{m}^{3} / \mathrm{hr}=170.04 \mathrm{gpm}$; Efficiency=55 \%; Power $=11.70$ $\mathrm{kW}=15.7 \mathrm{hp}$

Cooling Tower (Open Circuit)

Cooling Water Flow Rate $=38.62 \mathrm{~m}^{3} / \mathrm{hr}=170.04 \mathrm{gpm}$;

Makeup Water TDS $=400 \mathrm{mg} / \mathrm{L}$;

Blowdown TDS $=1500 \mathrm{mg} / \mathrm{L}$;

Cycles of Concentration $=3.75$;

Cooling Range $18^{\circ} \mathrm{F}=10^{\circ} \mathrm{C}$;

Evaporation Fraction $=0.018$; 
Blowdown Fraction $=0.0065$;

Drift Losses=0.00005;

Evaporation Loss $=0.70 \mathrm{~m}^{3} / \mathrm{hr}=3.06 \mathrm{gpm}$;

Blow Down loss $=0.25 \mathrm{~m}^{3} / \mathrm{hr}=1.11 \mathrm{gpm}$;

Drift loss $=0.00 \mathrm{~m}^{3} / \mathrm{hr}=0.01 \mathrm{gpm}$;

Makeup Water $=0.95 \mathrm{~m}^{3} / \mathrm{hr}=4.18 \mathrm{gpm}$;

Cooling tower duty $=448.89 \mathrm{~kW}$ and Refrigeration Ton ( $1 \mathrm{RT}=12000 \mathrm{BTU} / \mathrm{hr}$ )

Makeup water pump power

Differential Head $=4$ bar $=58$ psi;

Flow $=0.95 \mathrm{~m}^{3} / \mathrm{hr}=4.18 \mathrm{gpm}$;

Efficiency $=55 \%$;

Power $=0.19 \mathrm{~kW}=0.26 \mathrm{hp}$

Boiler

Syngas is used as fuel. Table 7 shows the boiler fuel requirement.

Table 7

Boiler Fuel Requirement

\begin{tabular}{llll}
\hline Requirement & Temperature ${ }^{\circ} \mathrm{C}$ & Pressure 'bar' & Enthalpy 'kJ/kg' \\
\hline Treated Water & 30 & 34 & -15683 \\
De-Aeration Steam / Steam & 300 & 32 & $-13101\left(60^{\circ} \mathrm{C}\right.$ Super heat) \\
Vent Steam & 108 & 0.345 & -13271 \\
Boiler Feed Water Temperature & 108 & 0.345 & -15525 \\
\hline
\end{tabular}

Minimum vent Steam Flow rate $=100 \mathrm{~kg} / \mathrm{hr}$.

Steam Required:

Process Steam for UCG $=803.75 \mathrm{~kg} / \mathrm{hr}$;

Blowdown @ 5\%=40.19 kg/hr;

De-Aeration Steam $=500.00 \mathrm{~kg} / \mathrm{hr}$;

Total Steam $=1343.94 \mathrm{~kg} / \mathrm{hr}$;

Steam Flow $=1343.9 \mathrm{~kg} / \mathrm{hr}$;

Enthalpy Change from Treated Water to Steam $=2582 \mathrm{~kJ} / \mathrm{kg}$;

Fuel BTU Value (Syn Gas) $=3860 \mathrm{~kJ} / \mathrm{kg}$ (From UGC Calculations);

Combustion Efficiency $=85$ \%; Required / Syn Gas $=1058 \mathrm{~kg} / \mathrm{hr}$.

Figure 7 shows the underground coal gasifier. Oxygen and steam flow rate in boiler are given in Table 8.

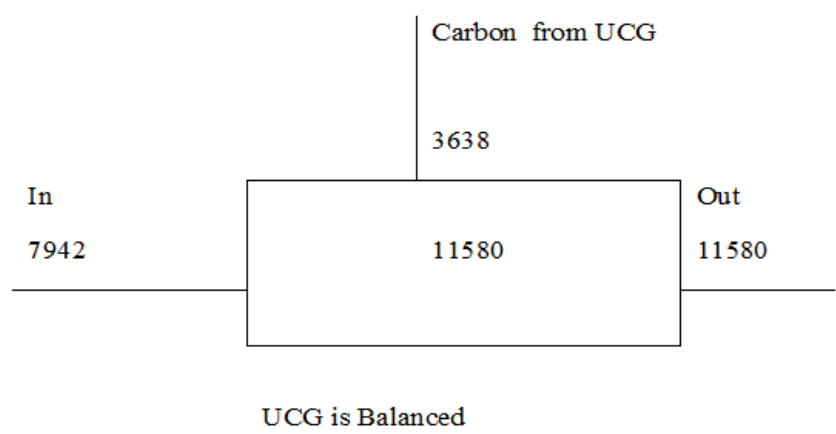

Fig. 7. Underground coal gasifier 


\section{Table 8}

Oxygen and steam flow rate in boiler

\begin{tabular}{llllll}
\hline Inlet & Flow & & & \multirow{2}{*}{ Temperature K } & Pressure barg \\
& $\mathrm{Nm}^{3} / \mathrm{hr}$ & $\mathrm{kg} / \mathrm{hr}$ & $\mathrm{kmol} / \mathrm{hr}$ & & 30 \\
Oxygen Flow Rate & 5000 & 7138.13 & 223.0749 & 315 & 30 \\
Steam Flow & 1000 & 803.753 & 44.61497 & 673 & \\
Total & 6000 & 7941.88 & 267.6898 & & \\
\hline
\end{tabular}

Combustion Temperature $=1600 \mathrm{~K}$;

GHSV $=0.01 \mathrm{hr}^{-1}$;

Exhaust Temperature $=500 \mathrm{~K}$;

UCG C in Coal Consumed $=3637.688892 \mathrm{~kg} / \mathrm{hr}=302.8631165 \mathrm{kmol} / \mathrm{hr}$;

Length of Reactor $=24.21 \mathrm{~m}$.

Simultaneous mass and energy balance is carried out in UCG Kinetic Simulator as shown in Table 9.

Table 9

Calculations of outlet yield gases

\begin{tabular}{|c|c|c|c|c|c|}
\hline Outlet & Yield & $\mathrm{Nm}^{3} / \mathrm{hr}$ & $\mathrm{kg} / \mathrm{hr}$ & $\mathrm{kmol} / \mathrm{hr}$ & Mole Fraction \\
\hline $\mathrm{O}_{2}$ & & 0 & 0 & 0 & 0.000 \\
\hline $\mathrm{H}_{2}$ & & 252.5 & 22.7 & 11.26 & 0.0324 \\
\hline $\mathrm{H}_{2} \mathrm{O}$ & & 747.5 & 600.8 & 33.35 & 0.0960 \\
\hline $\mathrm{CO}_{2}$ & & 3464.1 & 6801.8 & 154.55 & 0.4448 \\
\hline $\mathrm{CO}$ & & 3324.3 & 4154.3 & 148.31 & 0.4268 \\
\hline Total & & 7788.4 & 11579.6 & 347.48 & 1.0000 \\
\hline
\end{tabular}

BTU Value $=128624 \mathrm{~J} / \mathrm{mol}=5739 \mathrm{~kJ} / \mathrm{Nm}^{3}=146 \mathrm{BTU} / \mathrm{SCF} ; \mathrm{MW}=33.32 \mathrm{~kg} / \mathrm{kgmol}$

\subsection{Equipment Design}

\subsubsection{Compressor}

Table 10 displays the oxygen and steam flow rate in compressor.

Table 10

Oxygen and steam flow rate in compressor

\begin{tabular}{lllllll}
\hline \multirow{2}{*}{ Inlet } & Flow & & & \multicolumn{2}{c}{ Temp. } & \multicolumn{2}{c}{ Pressure } \\
& $\mathrm{Nm}^{3} / \mathrm{hr}$ & $\mathrm{kg} / \mathrm{hr}$ & $\mathrm{kmol} / \mathrm{hr}$ & $\mathrm{K}$ & $\mathrm{bar}$ & $\mathrm{psi}$ \\
\hline $\begin{array}{l}\text { Oxygen Flow Rate } \\
\begin{array}{l}\text { Oxygen flow rate in lb/min } \\
\text { Oulet }\end{array}\end{array}$ & 5000 & 7138.3 & 223.08 & 313 & 16 & 234.9 \\
Oxygen flow rate & 261.74 & & & & & \\
\hline
\end{tabular}

Compression ratio $=2.1875$;

Molecular weight $=32 ; \mathrm{R}=48.25$;

Suction temperature $=313 \mathrm{~K}=104^{\circ} \mathrm{F}=564 \mathrm{R}$;

Specific volume of oxygen at $315 \mathrm{~K}=0.80277 \mathrm{~m}^{3} / \mathrm{kg}$;

$\left(A=3.639, B \times 10^{\wedge} 3=0.593, C \times 10^{\wedge} 6=0, D \times 10^{\wedge}-5=0.04\right)$.

$\mathrm{CP} / \mathrm{R}=3.865438, \gamma=1.348987, \mathrm{Tc}=154 \mathrm{~K}, \mathrm{Pc}=50.43 \mathrm{bar}, \mathrm{Tr}=2.032467532, \mathrm{Pr}=0.317271$.

$Z=Z^{0}+w Z^{1}$, but for simple fluids the value of $w=0$ so, the equation reduces to $Z=Z 0$.

The thermodynamics value of $z$ is; $Z=0.997$; Polytropic efficiency $=0.85$; Adiabatic efficiency $=0.9$; 
Polytropic Coefficient $=1.437517568$

Adiabatic head; Adiabatic exponent $=0.258702879$

Factor ZKRT/(K-1) $=58201.68424$

$\mathrm{H}_{\mathrm{AD}}=13064.1$

Polytropic head; polytropic exponent $=1.437517568$

Factor ZRT/(N-1)N=49471.43161

Hpoly $=60574.92$

Horse power from adibatic head $=115.1318 \quad \mathrm{HP}=85.85377 \mathrm{~kW}=0.086 \mathrm{MW}$

Horse power from polytropic head $=565.2389 \mathrm{HP}=421.4986 \mathrm{~kW}$

\subsubsection{Gasifier design}

Figure 8 to 13 portrait the simulations for gasifier design using Gibbs's free energy model.

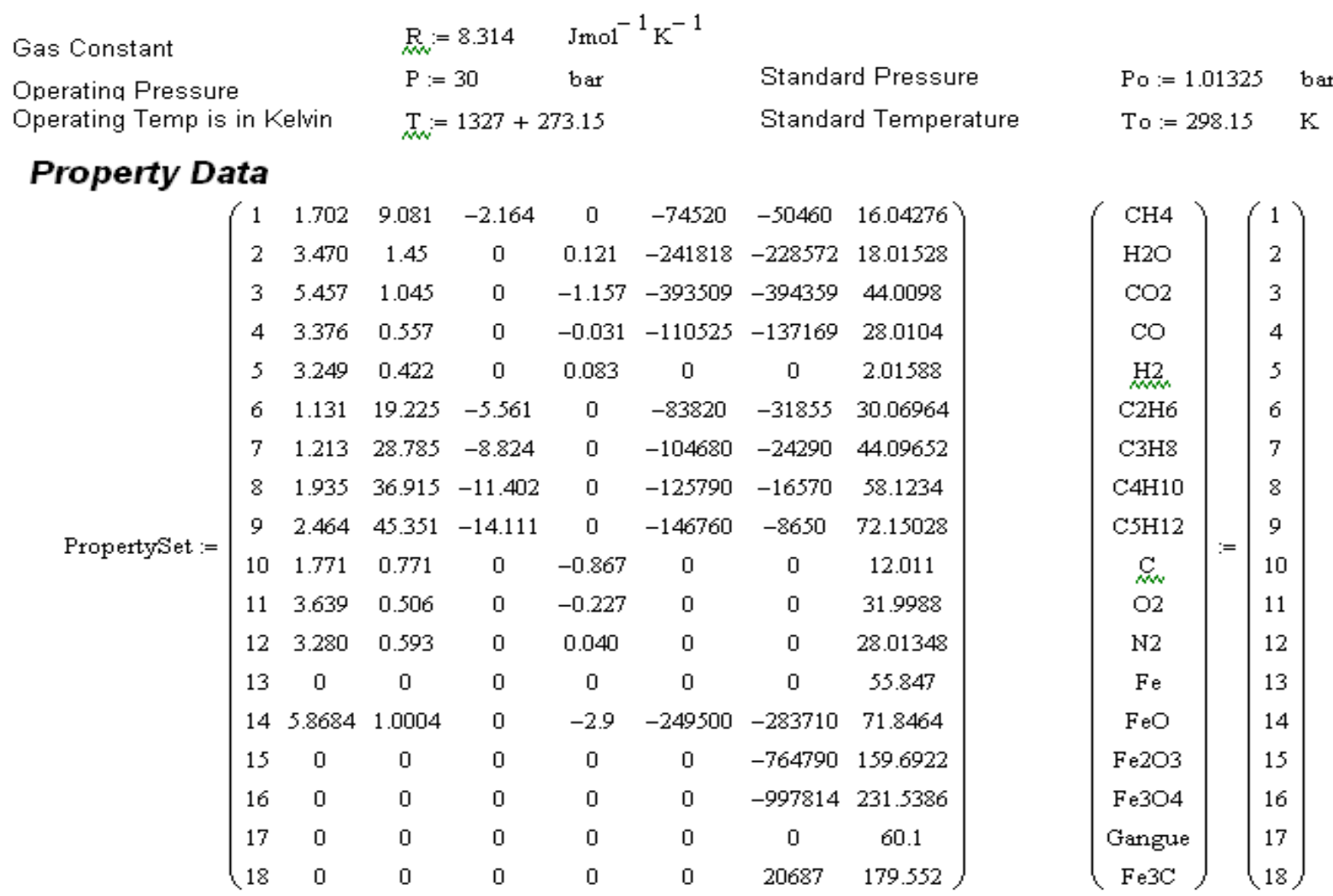

Fig. 8. Minimizing gibbs free energy for equilibrium composition 


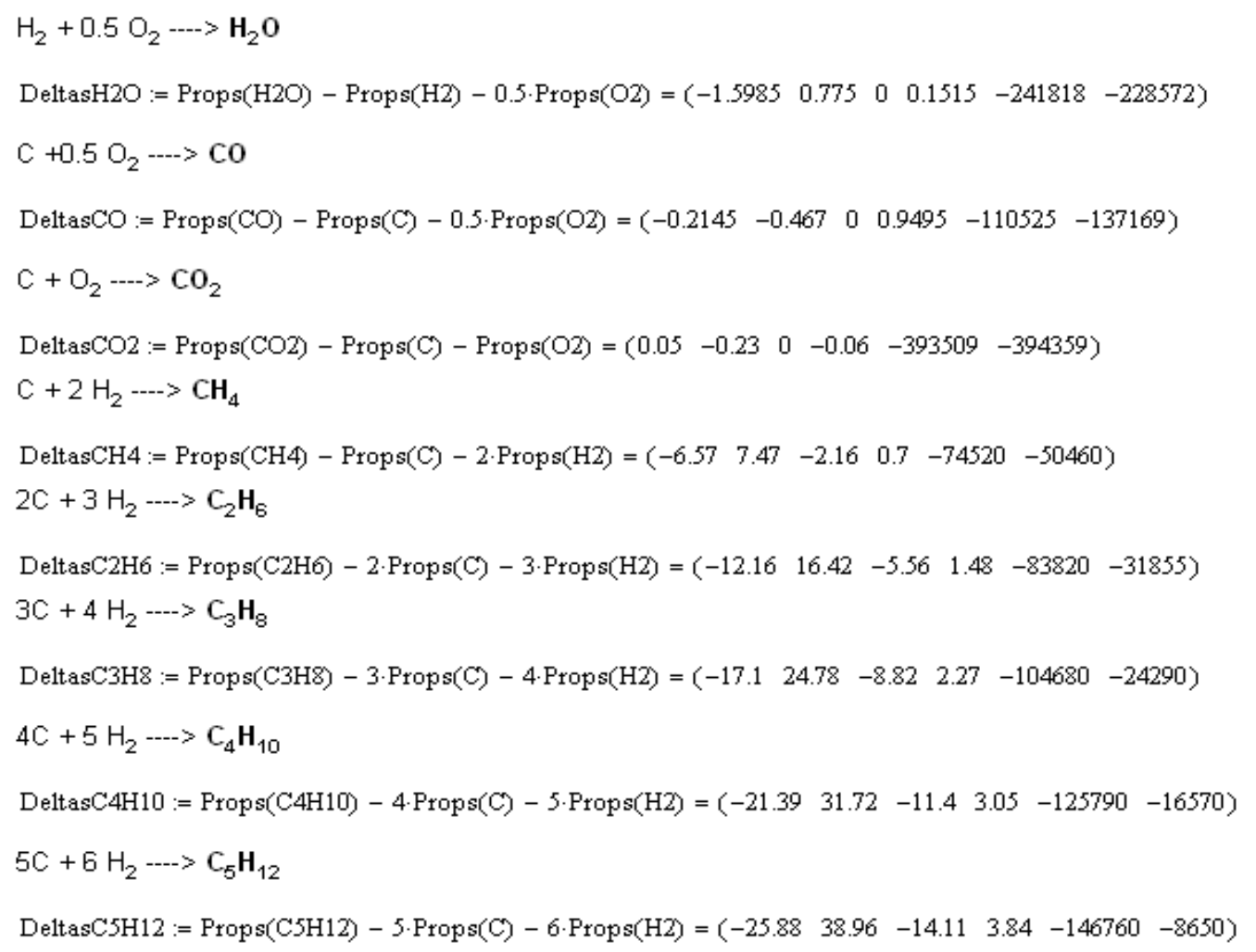

Fig. 9. Reaction deltas $(\Delta A, \Delta B, \Delta C, \Delta D, \Delta H, \Delta G)$ formation reactions

Reaction 01: Water-gas Shift Reaction

$\mathrm{CO}+\mathrm{H}_{2} \mathrm{O} \rightarrow-\mathrm{CO}_{2}+\mathrm{H}_{2}$

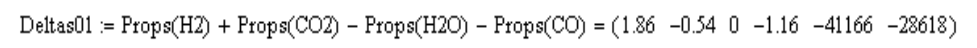

I_ $D($ Deltas 01$)=-48822.9 \quad$ J_D (Deltas01 $)=-18.01$

Reaction 02: $\mathrm{CO}_{2}$ Reforming

$\mathrm{CO}_{2}+\mathrm{CH}_{4} \rightarrow-\cdots 2 \mathrm{CO}+2 \mathrm{H}_{2}$

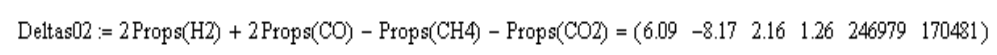

Reaction 03: $\mathrm{H}_{2} \mathrm{O}$ Reforming

I_D $($ Deltas02 $)=238256.2 \quad$ J_D (Deltas02 $)=-6.89$

$\mathrm{H}_{2} \mathrm{O}+\mathrm{CH}_{4} \rightarrow-\rightarrow \mathrm{CO}+3 \mathrm{H}_{2}$

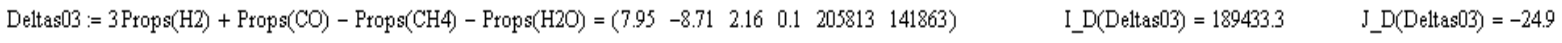

Reaction 04: Boudouard Reaction

$2 \mathrm{CO} \rightarrow \mathrm{CO}_{2}+\mathrm{C}$

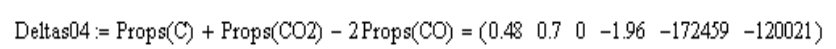

I_D $D($ Deltas04 $)=-179369.4 \quad$ J_D $($ Deltas04 $)=-25.66$

\section{Reaction 05: Beggs Reaction}

$\mathrm{CO}+\mathrm{H}_{2}-\cdots>\mathrm{C}+\mathrm{H}_{2} \mathrm{O}$

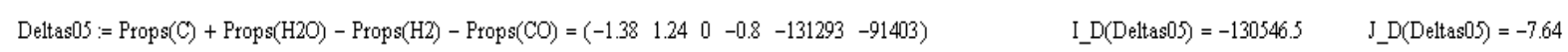

Reaction 06: Methane Cracking

$\mathrm{CH}_{4} \rightarrow-\rightarrow \mathrm{C}+2 \mathrm{H}_{2}$

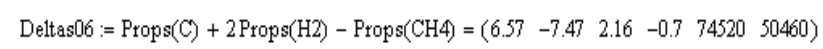

I_D(Deltas00) $=58886.8$

$J_{-} \mathrm{D}($ Deltas00) $=-32.54$

Fig. 10. Reaction deltas $(\Delta \mathrm{A}, \Delta \mathrm{B}, \Delta \mathrm{C}, \Delta \mathrm{D}, \Delta \mathrm{H}, \Delta \mathrm{G})$ general reactions 


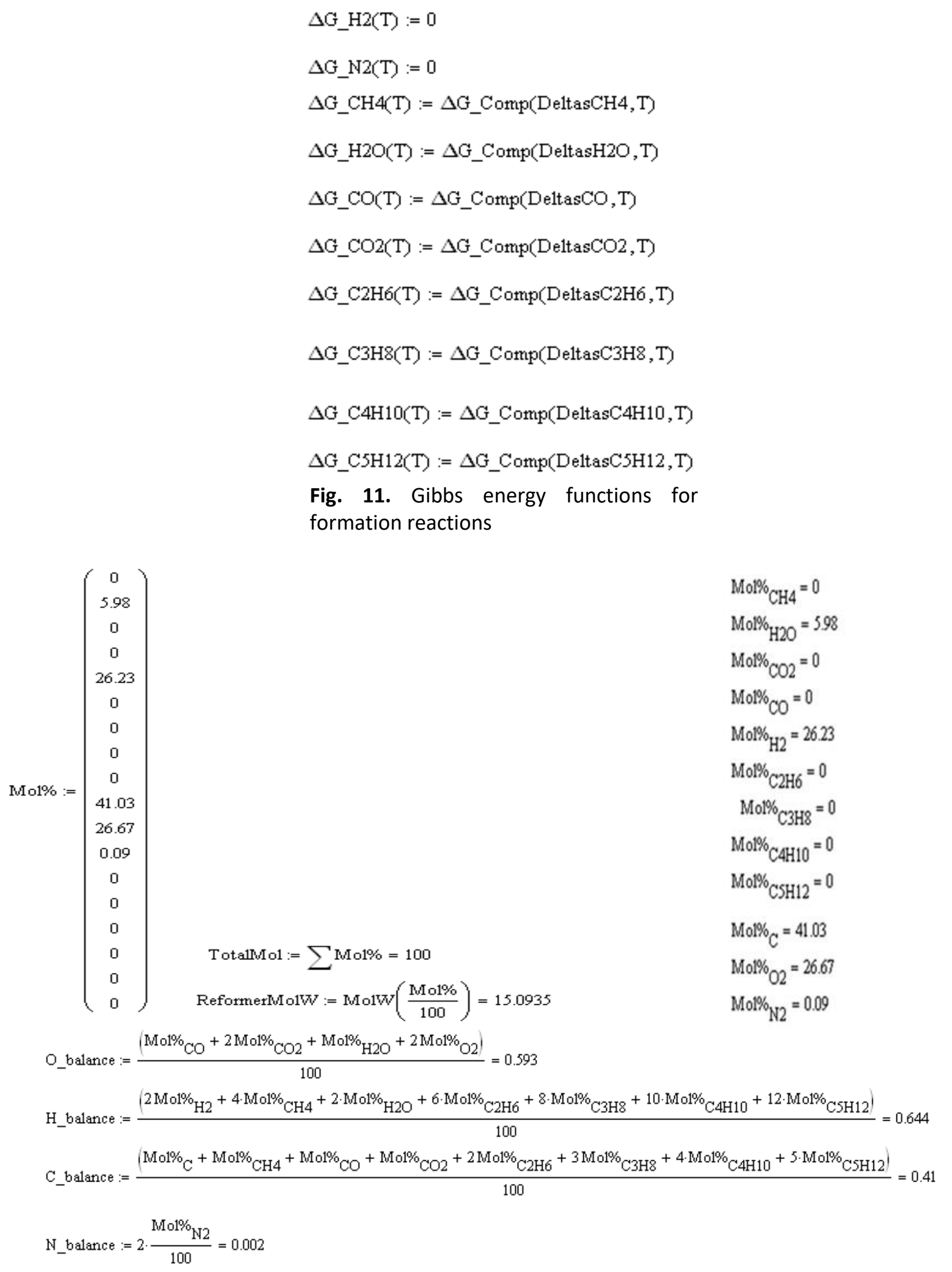

Fig. 12. Gas composition (Mole percentage) 
Initial guesses

$$
\begin{array}{lcclrl}
\mathrm{yH} 2 & :=0.2 & \mathrm{yCH} 4:=0.01 & \mathrm{yH} 2 \mathrm{O}:=0.05 & \mathrm{yCO}:=0.2 & \mathrm{yCO}:=0.01 \\
\mathrm{yN} 2:=0.01 \quad \mathrm{yC2H} 6:=0.1 & \mathrm{yC} 3 \mathrm{H} 8:=0.1 & \mathrm{yC4H} 10:=0.1 & \mathrm{yC} 5 \mathrm{H} 12:=0.1 \\
\mathrm{n}:=1 & \mathrm{yO2}:=0.1 & & & \\
\Lambda \mathrm{C}:=1 \cdot \mathrm{R} \cdot 1000 \mathrm{AH} & :=1 \cdot \mathrm{R} \cdot 100 \mathrm{AO}:=1 \cdot \mathrm{R} \cdot 1000 & \mathrm{AN}:=1 \cdot \mathrm{R} \cdot 1000 &
\end{array}
$$

Solving 15 equations and 15 variables simultaneously; $\mathrm{yCH}_{4}, \mathrm{yH}_{2} \mathrm{O}, \mathrm{yCO}, \mathrm{yCO}, \mathrm{yH}_{2}, \mathrm{yN}, \Delta \mathrm{C}, \Delta \mathrm{H}$, $\Delta \mathrm{O}, \Delta \mathrm{N}, \mathrm{n}, \mathrm{yC}_{2} \mathrm{H}_{6}, \mathrm{yC}_{3} \mathrm{H}_{8}, \mathrm{yC}_{4} \mathrm{H}_{10}, \mathrm{yC}_{5} \mathrm{H}_{12}$; given;

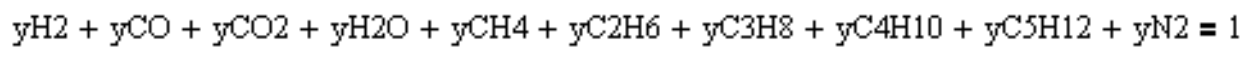

$$
\begin{aligned}
& 4 \cdot \mathrm{yCH} 4+2 \cdot \mathrm{yH} 2+2 \cdot \mathrm{yH} 2 \mathrm{O}+6 \cdot \mathrm{yC} 2 \mathrm{H} 6+8 \cdot \mathrm{yC} 3 \mathrm{H} 8+10 \cdot \mathrm{yC} 4 \mathrm{H} 10+12 \cdot \mathrm{yC} 5 \mathrm{H} 12=\frac{\mathrm{H} \_ \text {balance }}{\mathrm{n}}
\end{aligned}
$$

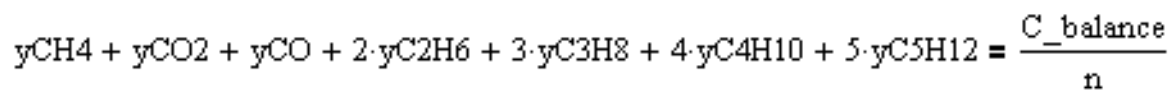

$$
\begin{aligned}
& \mathrm{yH} 2 \mathrm{O}+\mathrm{yCO}+2 \mathrm{yCO} 2+2 \cdot \mathrm{yO}_{2}=\frac{\mathrm{O}_{-} \mathrm{balance}}{\mathrm{n}} \\
& 2 \mathrm{yN} 2=\frac{\mathrm{N} \text { balance }}{\mathrm{n}} \\
& \frac{\Delta \mathrm{G}-\mathrm{H} 2(\mathrm{~T})}{\mathrm{R} \cdot \mathrm{T}}+\ln \left(\mathrm{yH} 2 \cdot \frac{\mathrm{P}}{\mathrm{Po}}\right)+2 \cdot \frac{\Delta \mathrm{H}}{\mathrm{R} \cdot \mathrm{T}}=0 \\
& \frac{\Delta \mathrm{G}_{-} \mathrm{CO}(\mathrm{T})}{\mathrm{R} \cdot \mathrm{T}}+\ln \left(\mathrm{y} \mathrm{CO} \cdot \frac{\mathrm{P}}{\mathrm{Po}_{\mathrm{O}}}\right)+\frac{\Lambda \mathrm{C}}{\mathrm{R} \cdot \mathrm{T}}+\frac{\Lambda \mathrm{O}}{\mathrm{R} \cdot \mathrm{T}}=0 \\
& \frac{\Delta \mathrm{G}_{-} \mathrm{N} 2(\mathrm{~T})}{\mathrm{R} \cdot \mathrm{T}}+\ln \left(\mathrm{yN} 2 \cdot \frac{\mathrm{P}}{\mathrm{Po}_{0}}\right)+\frac{2 \Lambda \mathrm{N}}{\mathrm{R} \cdot \mathrm{T}}=0 \\
& \mathrm{yCH} 4=\frac{\exp \left[-\left(\frac{\Delta \mathrm{G}_{-} \mathrm{CH} 4(\mathrm{~T})}{\mathrm{R} \cdot \mathrm{T}}+\frac{\Lambda \mathrm{C}}{\mathrm{R} \cdot \mathrm{T}}+\frac{4 \cdot \Lambda \mathrm{H}}{\mathrm{R} \cdot \mathrm{T}}\right)\right]}{\frac{\mathrm{P}}{\mathrm{P}_{0}}} \\
& \mathrm{y} C 2 \mathrm{H} 6=\frac{\exp \left[-\left(\frac{\Delta \mathrm{G}_{-} \mathrm{C} 2 \mathrm{H} 6(\mathrm{~T})}{\mathrm{R} \cdot \mathrm{T}}+\frac{2 \Lambda \mathrm{C}}{\mathrm{R} \cdot \mathrm{T}}+\frac{6 \cdot \Lambda \mathrm{H}}{\mathrm{R} \cdot \mathrm{T}}\right)\right]}{\left(\frac{\mathrm{P}}{\mathrm{Po}_{0}}\right)}
\end{aligned}
$$




$$
\begin{aligned}
& \mathrm{yC} 3 \mathrm{H} 8=\frac{\exp \left[-\left(\frac{\Delta \mathrm{G}_{-} \mathrm{C} 3 \mathrm{H} 8(\mathrm{~T})}{\mathrm{R} \cdot \mathrm{T}}+\frac{3 \Lambda \mathrm{C}}{\mathrm{R} \cdot \mathrm{T}}+\frac{8 \cdot \Lambda \mathrm{H}}{\mathrm{R} \cdot \mathrm{T}}\right)\right]}{\frac{\mathrm{P}}{\mathrm{P}_{0}}} \\
& \mathrm{yC} 4 \mathrm{H} 10=\frac{\exp \left[-\left(\frac{\Delta \mathrm{G}_{-} \mathrm{C} 4 \mathrm{H} 10(\mathrm{~T})}{\mathrm{R} \cdot \mathrm{T}}+\frac{4 \Lambda \mathrm{C}}{\mathrm{R} \cdot \mathrm{T}}+\frac{10 \cdot \Lambda \mathrm{H}}{\mathrm{R} \cdot \mathrm{T}}\right)\right]}{\left(\frac{\mathrm{P}}{\mathrm{P}_{0}}\right)}
\end{aligned}
$$

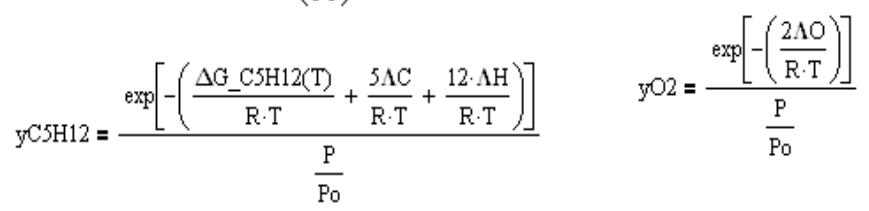

Limits

$$
\begin{aligned}
& 0<\mathrm{yCH} 4 \leq 1 \quad 0 \leq \mathrm{yH} 2 \mathrm{O} \leq 1 \quad 0 \leq \mathrm{yH} 2 \leq 1 \quad 0 \leq \mathrm{yO} \leq 1 \\
& 0 \leq \mathrm{yC} 2 \mathrm{H} 6 \leq 1 \quad 0 \leq \mathrm{yCO} 2 \leq 1 \quad 0 \leq \mathrm{yN} 2 \leq 1 \\
& 0 \leq \mathrm{yC} 3 \mathrm{H} 8 \leq 1 \quad 0 \leq \mathrm{yCO} \leq 1 \\
& 0 \leq \mathrm{yC} 4 \mathrm{H} 10 \leq 1 \\
& 0 \leq \mathrm{yCSH} 12 \leq 1
\end{aligned}
$$

$$
\frac{\Delta \mathrm{G}_{-} \mathrm{H} 2 \mathrm{O}(\mathrm{T})}{\mathrm{R} \cdot \mathrm{T}}+\ln \left(\mathrm{yH} 2 \mathrm{O} \cdot \frac{\mathrm{P}}{\mathrm{Po}_{\mathrm{O}}}\right)+\frac{2 \Lambda \mathrm{H}}{\mathrm{R} \cdot \mathrm{T}}+\frac{\Lambda \mathrm{O}}{\mathrm{R} \cdot \mathrm{T}}=0
$$

Fig. 13. Solving equations

Parametric Function

Yield $(T)=F i n d\left(\mathrm{yCH}_{4}, \mathrm{yH}_{2} \mathrm{O}, \mathrm{yCO}, \mathrm{yCO}, \mathrm{yH}_{2}, \mathrm{yC}_{2} \mathrm{H}_{6}, \mathrm{yC}_{3} \mathrm{H}_{8}, \mathrm{yC}_{4} \mathrm{H}_{10}, \mathrm{yC}_{5} \mathrm{H}_{12}, \mathrm{yN}_{2}, y \mathrm{O}_{2}, \mathrm{n}, \Delta \mathrm{C}, \Delta \mathrm{H}, \Delta \mathrm{O}, \Delta \mathrm{N}\right)$ $v=$ Yeild $(1327+273.15)$

Results;

$\mathrm{yCH}_{4}=\mathrm{v}_{1}=0.0001 ; \mathrm{yH}_{2} \mathrm{O}=\mathrm{v}_{2}=0.1589 ; \mathrm{yCO}_{2}=\mathrm{v}_{3}=0.0907 ; \mathrm{yCO}=\mathrm{v}_{4}=0.4689 ; \mathrm{yH}_{2}=\mathrm{v}_{5}=0.2803 ; \mathrm{yC}_{2} \mathrm{H}_{6}=\mathrm{v}_{6}=0 ;$ $\mathrm{yC}_{3} \mathrm{H}_{8}=\mathrm{v}_{7}=0 ; \mathrm{yC}_{4} \mathrm{H}_{10}=\mathrm{v}_{8}=0 ; \mathrm{yC}_{5} \mathrm{H}_{12}=\mathrm{v}_{9}=0 ; \mathrm{yN2}=\mathrm{v}_{10}=0.0012 ; \mathrm{yO}_{2}=\mathrm{v}_{11}=4.8571 \times 10^{-13} ; \mathrm{n}=\mathrm{v}_{12}=0.7332 ;$ $\Delta \mathrm{C}=\mathrm{v}_{13}=51401.47 ; \Delta \mathrm{H}=\mathrm{v}_{14}=14075.85 ; \Delta \mathrm{O}=\mathrm{v}_{15}=166063.59 ; \Delta \mathrm{N}=\mathrm{v}_{16}=22048.94$

\subsubsection{UCG kinetic simulator}

Table 11 shows the exhaust gas properties.

Steam Feed Rate $=1000 \mathrm{Nm}^{3} / \mathrm{hr}=44.61497 \mathrm{kmol} / \mathrm{hr}$;

Oxygen Flow Rate $=5000 \mathrm{Nm}^{3} / \mathrm{hr}=223.0749 \mathrm{kmol} / \mathrm{hr}$;

Radius of Tube $=1 \mathrm{~m}$;

Density $=833 \mathrm{~kg} / \mathrm{m}^{3}$;

Thickness $=0.001 \mathrm{~m}$;

Effectivity=0.4; GHSV=0.01 hr-1;

Combustion Temperature $=1600 \mathrm{~K}$;

Cutoff Temperature $=500 \mathrm{~K}$; Step Size $=1 \mathrm{~m}$ and Factor $=0.020946$ 


\section{Table 11}

Exhaust gas properties

\begin{tabular}{|c|c|c|c|c|c|c|c|c|c|c|}
\hline \multicolumn{11}{|c|}{ Exhaust Gas Properties } \\
\hline \multicolumn{6}{|c|}{ Flows kmol/hr } & $\begin{array}{l}\text { Length } \\
\text { Reactor }\end{array}$ & Sum & $\begin{array}{l}\text { BTU } \\
\text { Value }\end{array}$ & MW & Flow \\
\hline $\mathrm{O}_{2}$ & $\mathrm{H}_{2}$ & $\mathrm{H}_{2} \mathrm{O}$ & $\mathrm{CO}_{2}$ & $\mathrm{CO}$ & $\mathrm{CH}_{4}$ & $m$ & $\mathrm{kmol} / \mathrm{hr}$ & BTU/SCF & $\mathrm{kg} / \mathrm{kmol}$ & $\mathrm{kg} / \mathrm{hr}$ \\
\hline 0.0 & 11.265 & 33.350 & 154.552 & 148.312 & 0.0 & 24.210 & 347.478 & 146.02 & 128623.54 & 5738.536 \\
\hline
\end{tabular}

Sulphur Content;

delta $\mathrm{G}=41170+27.36 \mathrm{~T}=54850$

In $\mathrm{K}=(-\mathrm{G} / \mathrm{RT})=-13.19461$

$\mathrm{K}=1.861^{\wedge}-6$

$\mathrm{K}=\left[\mathrm{H}_{2} \mathrm{~S}\right] /[\mathrm{H}]$

The concentration of $\mathrm{H}_{2}$ gas 0.0342 , multiply it with value of $\mathrm{K}$, to get the concentration of $\mathrm{H}_{2} \mathrm{~S}$. Concentration of $\mathrm{H}_{2} \mathrm{~S}=0.0008233$. This is very low value. Hence concentration of sulphur in product gas maybe neglected. Figure 14 to17 represents the graphical summary of the gasifier.

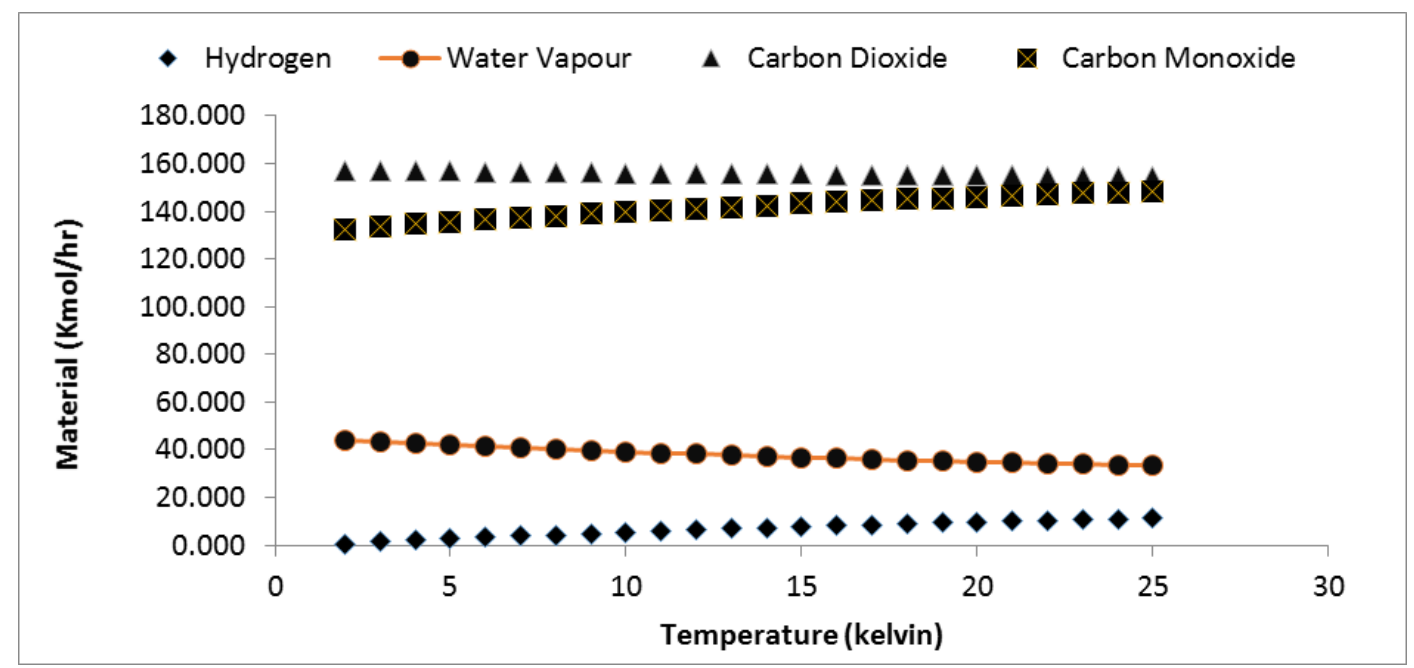

Fig. 14. Formation of gas species with respect to distance

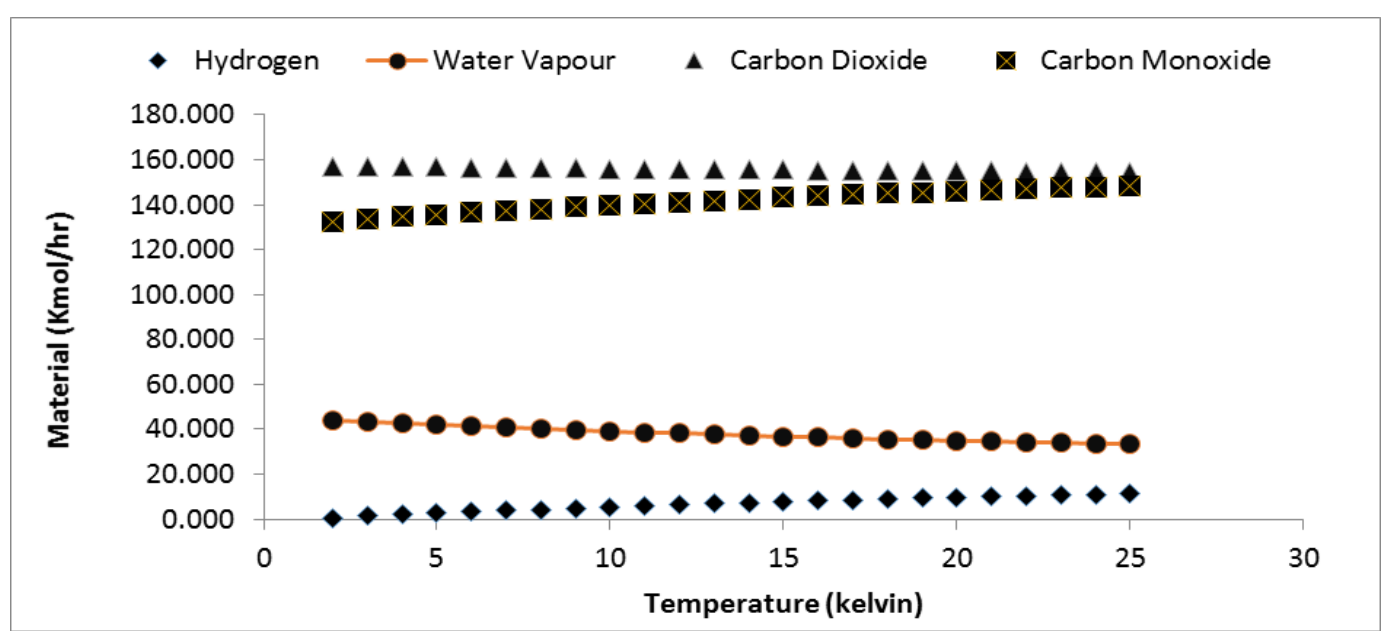

Fig. 15. Formation of gas species with respect to temperature 


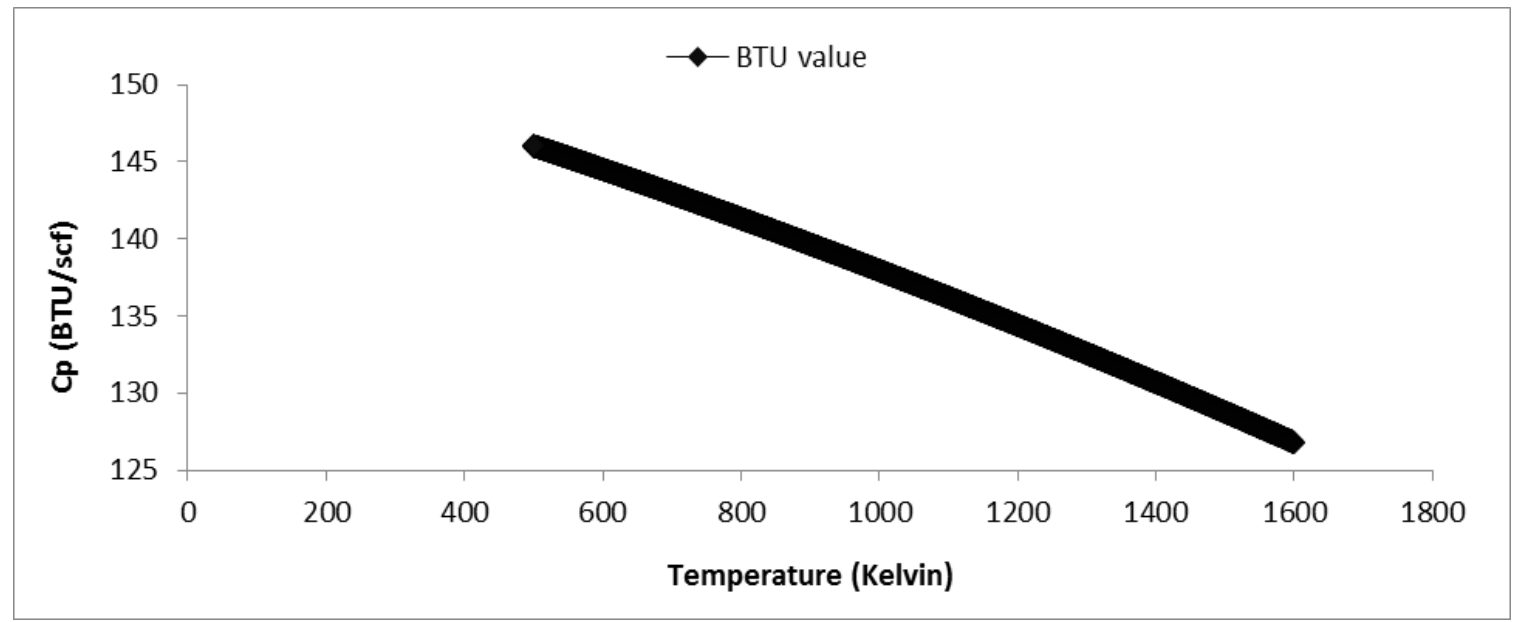

Fig. 16. BTU value with respect to temperature

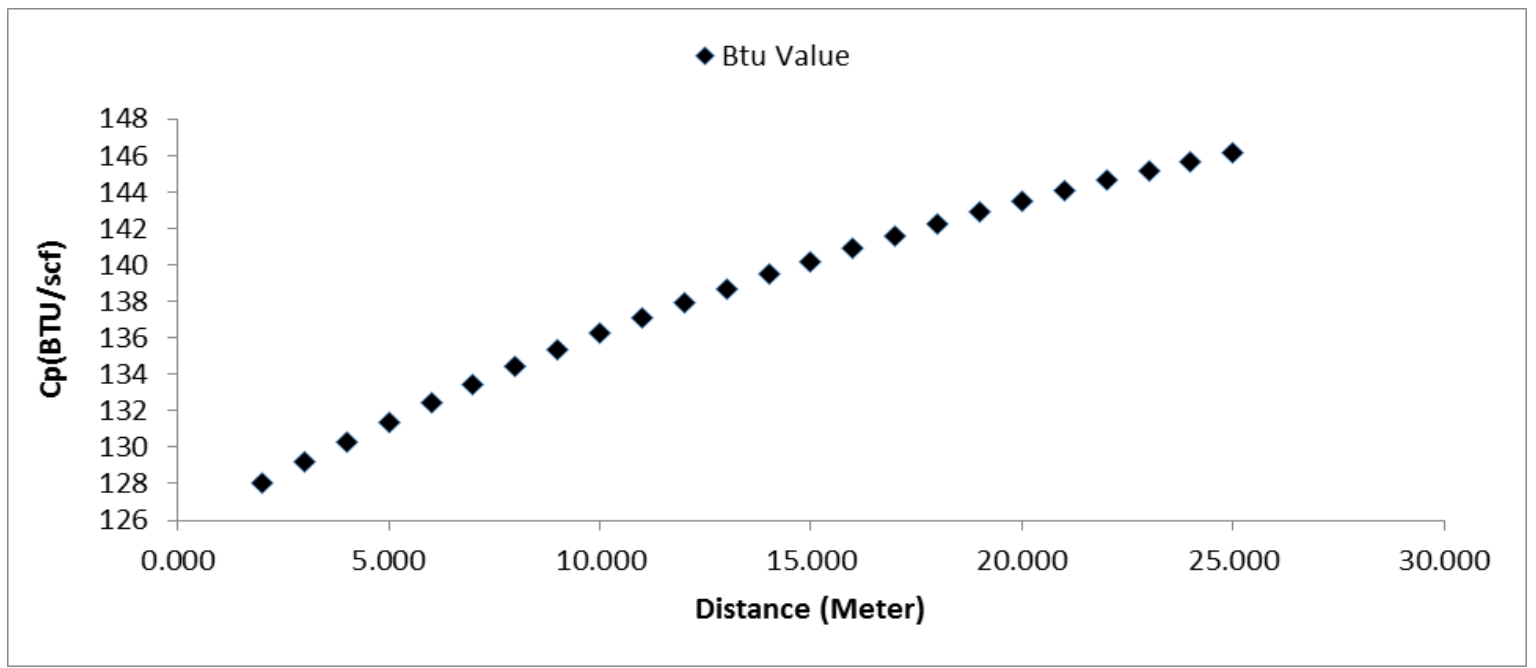

Fig. 17. BTU value with respect to distance

Turbine calculations

Combustion temperature $=\mathrm{Ti}=2000 \mathrm{~K}$,

Polytropic efficiency $=\rho T=0.99$,

$\mathrm{CP} / \mathrm{CV}=\mathrm{\gamma}=1.3$,

Inlet Pressure $=\mathrm{P} 1=30$ bar,

Outlet Pressure $=\mathrm{P} 2=1$ bar,

Pressure Ratio $=P 1 / P 2=30$,

For Turbine $=(n-1) / n=0.228462$,

$\mathrm{Cp}=1.37$,

$\mathrm{m}=13351.5 \mathrm{Kg} / \mathrm{Hr}=3.70875 \mathrm{~kg} / \mathrm{sec}$,

$\Delta \mathrm{T}=1080.473 \mathrm{~K}$,

$\mathrm{W}=5489.869 \mathrm{~kW}=5.489869 \mathrm{MW}$

\section{Cyclones}

Figure 18 show the schematic diagram for cyclone. Tables 12 and 13 show the iterative and efficiency calculations for cyclone 1. 
Cyclone 1; Cyclone Characteristics

Actual Gas Flow $\left(Q_{G}\right)=129.8062258 \mathrm{~m}^{3} / \mathrm{min}$;

Body Diameter $(\mathrm{D})=1.4 \mathrm{M}$;

Total Height of Cyclone $(\mathrm{H})=4.32$

$\mathrm{M}$; Height of Inlet $(\mathrm{a})=0.432 \mathrm{M}$;

Width of Inlet $(b)=0.432 \mathrm{M}$;

Diameter of the Vortex Finder $\left(D_{x}\right)=0.594 \mathrm{M}$;

Length of the Vortex Finder $(S)=0.54 \mathrm{M}$;

Height of Conical Section $\left(\mathrm{H}_{\mathrm{C}}\right)=2.7 \mathrm{M}$;

Diameter of Dust Exit $\left(D_{D}\right)=0.324 \mathrm{M}$;

Inlet Type $=$ Wrap Around;

Vortex Finder Edges=Rounded;

Cyclone Body Type (Cylindrical $/$ Conical) $=$ Conical;

Cyclone roughness $\left(k_{s}\right)=0.05 \mathrm{Mm}$;

Correction Factor for cut diameter $\left(\mathrm{x}_{\text {fact }}\right)=1$;

Slope of Grade Efficiency Curve $(m)=5$;

Estimated Efficiency (Starting Value) $=h_{E S T}=0.9$ and Width to Radius Ratio $(x)=0.617142857$

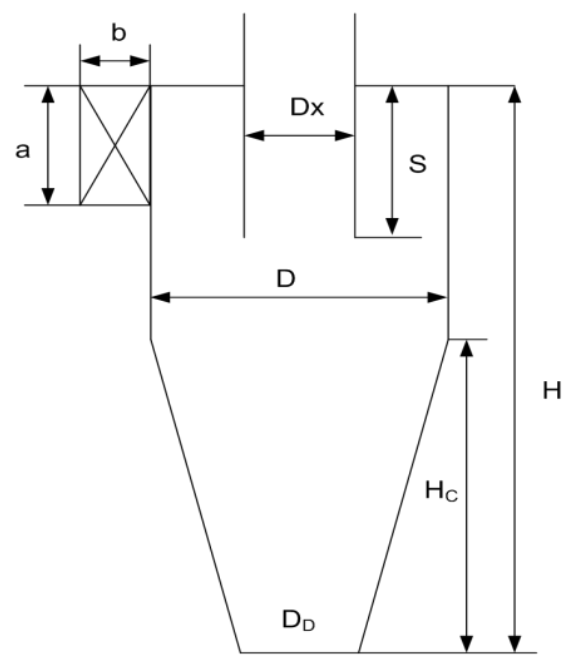

Fig. 18. Cyclone

Gas Properties;

Actual Gas Flow $\left(Q_{G}\right)=2.163 \mathrm{~m}^{3} / \mathrm{s}$;

Density $(r)=20.84 \mathrm{~kg} / \mathrm{m}^{3}$;

Dust Mass Loading $\left(M_{O}\right)=0.06 \mathrm{~kg} / \mathrm{m}^{3}$;

Dust Loading $\left(C_{o}\right)=0.00288 \mathrm{~kg} / \mathrm{kg}$;

Gas Vortex Slip Fraction $\left(S_{f}\right)=0.1$ and Gas Viscosity $(m)=2.43 \mathrm{E}-05$ Pa.s

Dust Properties;

Dust Density $\left(r_{P}\right)=690 \mathrm{~kg} / \mathrm{m}^{3}$;

Strand Density to Dust Density Ratio $(j)=0.4$;

Strand Density $\left(r_{\text {STR }}\right)=276 \mathrm{~kg} / \mathrm{m}^{3}$;

Median Particle Size $\left(x_{\text {med }}\right)=50 \mathrm{Mm}$ 
Muschelknautz Method;

Total Wall Area of Cyclone Separation Space $\left(A_{R}\right)=16.85 \mathrm{~m}^{3}$;

Inlet Velocity $\left(V_{I N}\right)=11.59 \mathrm{~m} / \mathrm{s}$;

Relative Roughness $\left(2 k_{s} / D\right)=0.000071$;

Relative Roughness Taken $\left(2 k_{S} / D\right)=0.000600$;

Ratio of Moment of Momenta Inlet to Wall Gas Flow $(a)=1.000$;

(For wrap around inlets $\mathrm{a}=1$ );

Radial Position of Center of Inlet $\left(R_{I N}\right)=0.48 \mathrm{M}$;

Geometric Mean Radius $\left(R_{M}\right)=0.46 \mathrm{M}$;

Wall Axial Velocity $\left(V_{z w}\right)=2.20 \mathrm{~m} / \mathrm{s}$;

Wall Velocity $\left(V_{q w}\right)=8.01 \mathrm{~m} / \mathrm{s}$;

Vortex Finder Velocity $\left(V_{X}\right)=7.81 \mathrm{~m} / \mathrm{s}$;

Friction Factor Starting value $(f)=0.00580$;

Froude's Number $\left(F_{r x}\right)=3.236$.

Table 12

Iterative Calculations for Cyclone 1

\begin{tabular}{llllll}
\hline Iterative Calculations & & & & & \\
\hline & $n$ & 0 & 1 & 2 & 3 \\
& $f_{(n)}$ & 0.00580 & 0.00411 & 0.00411 & 0.00411 \\
Core Spin Velocity & $V_{q C S}$ & 14.77 & 15.77 & 15.77 & 15.77 \\
$\begin{array}{l}\text { Muschelknautz and Trefz Cyclone } \\
\text { body Reynolds Number }\end{array}$ & $R_{R}$ & 92481.50 & 92711.92 & 92711.92 & 92711.92 \\
& $f_{S M}$ & 0.00026 & 0.00026 & 0.00026 & 0.00026 \\
& $f_{R}$ & 0.000169 & 0.000169 & 0.000169 & 0.000169 \\
Friction Factor for Air & $f_{A I R}$ & 0.00043 & 0.00043 & 0.00043 & 0.00043 \\
Friction Facor (iterating) & $f_{(n+1)}$ & 0.00411 & 0.00411 & 0.00411 & 0.00411 \\
\hline
\end{tabular}

Core Spin Velocity $\left(V_{q c s}\right)=15.77000 \mathrm{~m} / \mathrm{s}$;

Muschelknautz and Trefz Cyclone body Reynolds Number $\left(R_{e R}\right)=92711.9$;

Friction Facor $(f)=0.00411$;

Cut-Diameter $\left(x_{50}\right)=0.000015 \mathrm{~m}=14.7 \mathrm{~mm}$;

Critical Mass Loading $\left(C_{O L}\right)=0.001363 \mathrm{~kg} / \mathrm{kg}$;

Pressure Drop across body $\left(D p_{B O D Y}\right)=10016 \mathrm{~Pa}$;

Vortex Finder Pressure Drop $\left(D p_{X}\right)=45651 \mathrm{~Pa}$;

Total Pressure Drop $(D p)=55668$ Pa.

Table 13

Efficiency Calculations for Cyclone 1

\begin{tabular}{lllll}
\hline $\mathrm{xi}$ & $\mathrm{Ni}$ & $\mathrm{MF}<\mathrm{xi}$ & delta MF & delta MF*ni \\
\hline 0.05 & $7.53791 \mathrm{E}-09$ & 0.00120 & $9 \mathrm{E}-14$ & $6.82 \mathrm{E}-24$ \\
0.09 & $1.3717 \mathrm{E}-07$ & 0.00390 & $5.3 \mathrm{E}-12$ & $7.34 \mathrm{E}-21$ \\
0.15 & $1.66801 \mathrm{E}-06$ & 0.00790 & $1.3 \mathrm{E}-10$ & $2.2 \mathrm{E}-18$ \\
0.5 & 0.000501182 & 0.01200 & $6 \mathrm{E}-08$ & $3.01 \mathrm{E}-13$ \\
1 & 0.010563438 & 0.01370 & $1.4 \mathrm{E}-06$ & $1.53 \mathrm{E}-10$ \\
2 & 0.16077663 & 0.02070 & $3.3 \mathrm{E}-05$ & $5.35 \mathrm{E}-08$ \\
5 & 2.774499377 & 0.03460 & 0.00096 & $2.66 \mathrm{E}-05$ \\
8 & 8.051595078 & 0.07140 & 0.00575 & 0.000463 \\
10 & 12.16084883 & 0.17050 & 0.02073 & 0.002521 \\
30 & 44.70732155 & 0.37630 & 0.16823 & 0.075213 \\
70 & 69.69854728 & 0.63430 & 0.4421 & 0.308136 \\
100 & 77.46039167 & 1.00000 & 0.7746 & 0.600011 \\
& & & sum & 0.986371 \\
\hline
\end{tabular}


Efficiency 0.991701

Cyclone 2; Cyclone Characteristics

Table 14 and 15 show the iterative and efficiency calculations for Cyclone 2.

Actual Gas Flow (QG) $=129.8062258 \mathrm{~m}^{3} / \mathrm{min}$;

Body Diameter $(D)=1.4 \mathrm{M}$;

Total Height of Cyclone $(H)=4.32$

$\mathrm{M}$; Height of Inlet $(a)=0.432 \mathrm{M}$;

Width of Inlet $(b)=0.432 \mathrm{M}$;

Diameter of the Vortex Finder $\left(D_{X}\right)=0.594 \mathrm{M}$;

Length of the Vortex Finder $(S)=0.54 \mathrm{M}$;

Height of Conical Section $\left(H_{C}\right)=2.7 \mathrm{M}$;

Diameter of Dust Exit $\left(D_{D}\right)=0.324 \mathrm{M}$;

Inlet Type=Wrap Around;

Vortex Finder Edges=Rounded;

Cyclone Body Type (Cylindrical $/$ Conical $)=$ Conical;

Cyclone roughness $\left(k_{s}\right)=0.05 \mathrm{Mm}$;

Correction Factor for cut diameter $\left(x_{\text {fact }}\right) 1$;

Slope of Grade Efficiency Curve $(m)=5$;

Estimated Efficiency (Starting Value) $=h_{E S T}=0.9$;

Width to Radius Ratio $(x)=0.617142857$

Gas Properties;

Actual Gas Flow $\left(Q_{G}\right)=2.163 \mathrm{~m}^{3} / \mathrm{s}$;

Density $(r)=20.84 \mathrm{~kg} / \mathrm{m}^{3}$;

Dust Mass Loading $\left(M_{0}\right)=0.06 \mathrm{~kg} / \mathrm{m}^{3}$;

Dust Loading $\left(C_{o}\right)=0.00288 \mathrm{~kg} / \mathrm{kg}$;

Gas Vortex Slip Fraction $\left(S_{f}\right)=0.1$;

Gas Viscosity $(m)=2.43 \mathrm{E}-05$ Pa.s.

Dust Properties;

Dust Density $\left(r_{P}\right)=350 \mathrm{~kg} / \mathrm{m}^{3}$;

Strand Density to Dust Density Ratio $(j)=0.4$;

Strand Density $\left(r_{S T R}\right)=276 \mathrm{~kg} / \mathrm{m}^{3}$;

Median Particle Size $\left(x_{\text {med }}\right)=50 \mathrm{Mm}$

Muschelknautz Method;

Total Wall Area of Cyclone Separation Space $\left(A_{R}\right)=16.85 \mathrm{~m}^{3}$;

Inlet Velocity $\left(V_{I N}\right)=11.59 \mathrm{~m} / \mathrm{s}$;

Relative Roughness $\left(2 k_{s} / D\right)=0.000071$;

Relative Roughness Taken $\left(2 k_{s} / D\right)=0.000600$;

Ratio of Moment of Momenta Inlet to Wall Gas Flow $(a)=1.000$;

(For wrap around inlets $\mathrm{a}=1$ );

Radial Position of Center of Inlet $\left(R_{I N}\right)=0.48 \mathrm{M}$;

Geometric Mean Radius $\left(R_{M}\right)=0.46 \mathrm{M}$;

Wall Axial Velocity $\left(V_{z w}\right)=2.20 \mathrm{~m} / \mathrm{s}$; 
Wall Velocity $\left(V_{q w}\right)=8.01 \mathrm{~m} / \mathrm{s}$;

Vortex Finder Velocity $\left(V_{x}\right)=7.81 \mathrm{~m} / \mathrm{s}$;

Friction Factor Starting value $(f)=0.00580$;

Froude's Number $\left(F_{r X}\right)=3.236$

\section{Table 14}

Iterative Calculations for Cyclone 2

\begin{tabular}{llllll}
\hline Iterative Calculations & $n$ & 0 & 1 & 2 & 3 \\
& $f_{(n)}$ & 0.00580 & 0.00411 & 0.00411 & 0.00411 \\
Core Spin Velocity & $V_{q C S}$ & 14.77 & 15.77 & 15.77 & 15.77 \\
Muschelknautz and Trefz Cyclone & $R e_{R}$ & 92481.50 & 92711.92 & 92711.92 & 92711.92 \\
body Reynolds Number & $f_{S M}$ & 0.00026 & 0.00026 & 0.00026 & 0.00026 \\
& $f_{R}$ & 0.000169 & 0.000169 & 0.000169 & 0.000169 \\
Friction Factor for Air & $f_{A / R}$ & 0.00043 & 0.00043 & 0.00043 & 0.00043 \\
Friction Facor (iterating) & $f_{(n+1)}$ & 0.00411 & 0.00411 & 0.00411 & 0.00411 \\
\hline
\end{tabular}

Table 15

Efficiency Calculations for Cyclone 2

\begin{tabular}{lllll}
\hline $\mathrm{xi}$ & $\mathrm{Ni}$ & $\mathrm{MF}<\mathrm{xi}$ & delta MF & delta MF*ni \\
\hline 0.05 & $7.53791 \mathrm{E}-09$ & 0.00120 & $9 \mathrm{E}-14$ & $6.82 \mathrm{E}-24$ \\
0.09 & $1.3717 \mathrm{E}-07$ & 0.00390 & $5.3 \mathrm{E}-12$ & $7.34 \mathrm{E}-21$ \\
0.15 & $1.66801 \mathrm{E}-06$ & 0.00790 & $1.3 \mathrm{E}-10$ & $2.2 \mathrm{E}-18$ \\
0.5 & 0.000501182 & 0.01200 & $6 \mathrm{E}-08$ & $3.01 \mathrm{E}-13$ \\
1 & 0.010563438 & 0.01370 & $1.4 \mathrm{E}-06$ & $1.53 \mathrm{E}-10$ \\
2 & 0.16077663 & 0.02070 & $3.3 \mathrm{E}-05$ & $5.35 \mathrm{E}-08$ \\
5 & 2.774499377 & 0.03460 & 0.00096 & $2.66 \mathrm{E}-05$ \\
8 & 8.051595078 & 0.07140 & 0.00575 & 0.000463 \\
10 & 12.16084883 & 0.17050 & 0.02073 & 0.002521 \\
30 & 44.70732155 & 0.37630 & 0.16823 & 0.075213 \\
70 & 69.69854728 & 0.63430 & 0.4421 & 0.308136 \\
100 & 77.46039167 & 1.00000 & 0.7746 & 0.600011 \\
& & & sum & 0.986371 \\
\hline
\end{tabular}

Efficiency 0.787766

Core Spin Velocity $\left(V_{q c s}\right)=15.77000 \mathrm{~m} / \mathrm{s}$;

Muschelknautz and Trefz Cyclone body Reynolds Number $\left(R_{e R}\right)=92711.9$;

Friction Facor $(f)=0.00411$;

Cut-Diameter $\left(x_{50}\right)=0.000015 \mathrm{~m}=14.7 \mathrm{Mm}$;

Critical Mass Loading $\left(C_{O L}\right)=0.001363 \mathrm{~kg} / \mathrm{kg}$;

Pressure Drop across body $\left(D p_{B O D Y}\right)=10016 \mathrm{~Pa}$;

Vortex Finder Pressure Drop $\left(D p_{X}\right)=45651 \mathrm{~Pa}$;

Total Pressure Drop $(D p)=55668 \mathrm{~Pa}$.

\subsubsection{Heat exchanger 1 (Syngas cooler)}

The designing of syngas cooler proved to be out of scope for us since it is a two-phase heat exchanger as shown in Figure 19 and 20 [24]. Thus, heat exchanger software was used to design the syngas cooler by using the process conditions of our own. 


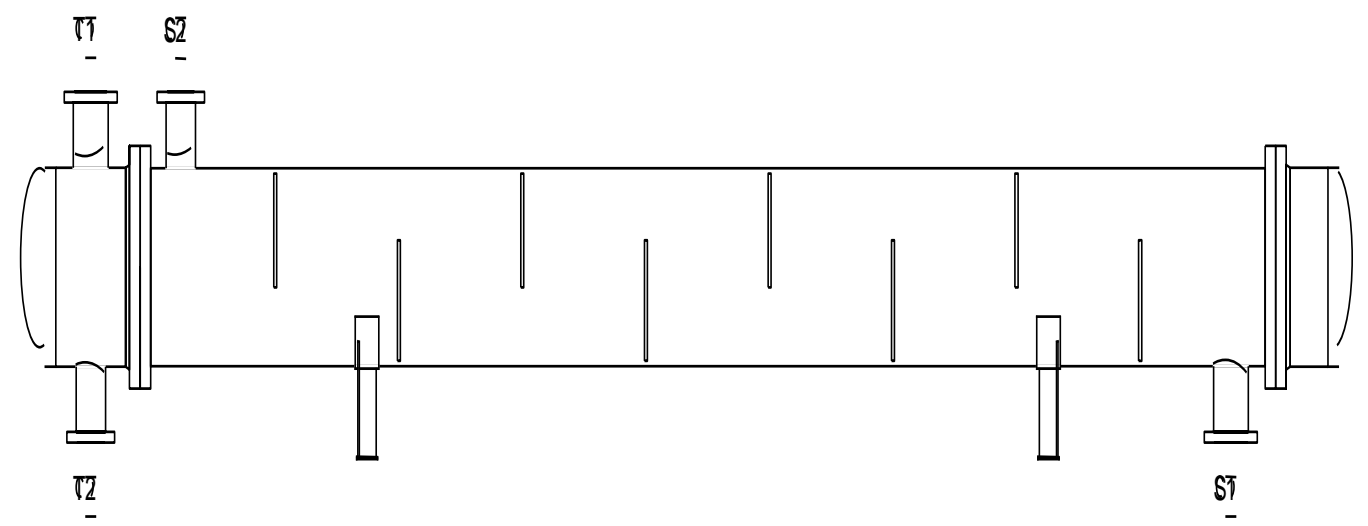

Fig. 19. Heat exchanger

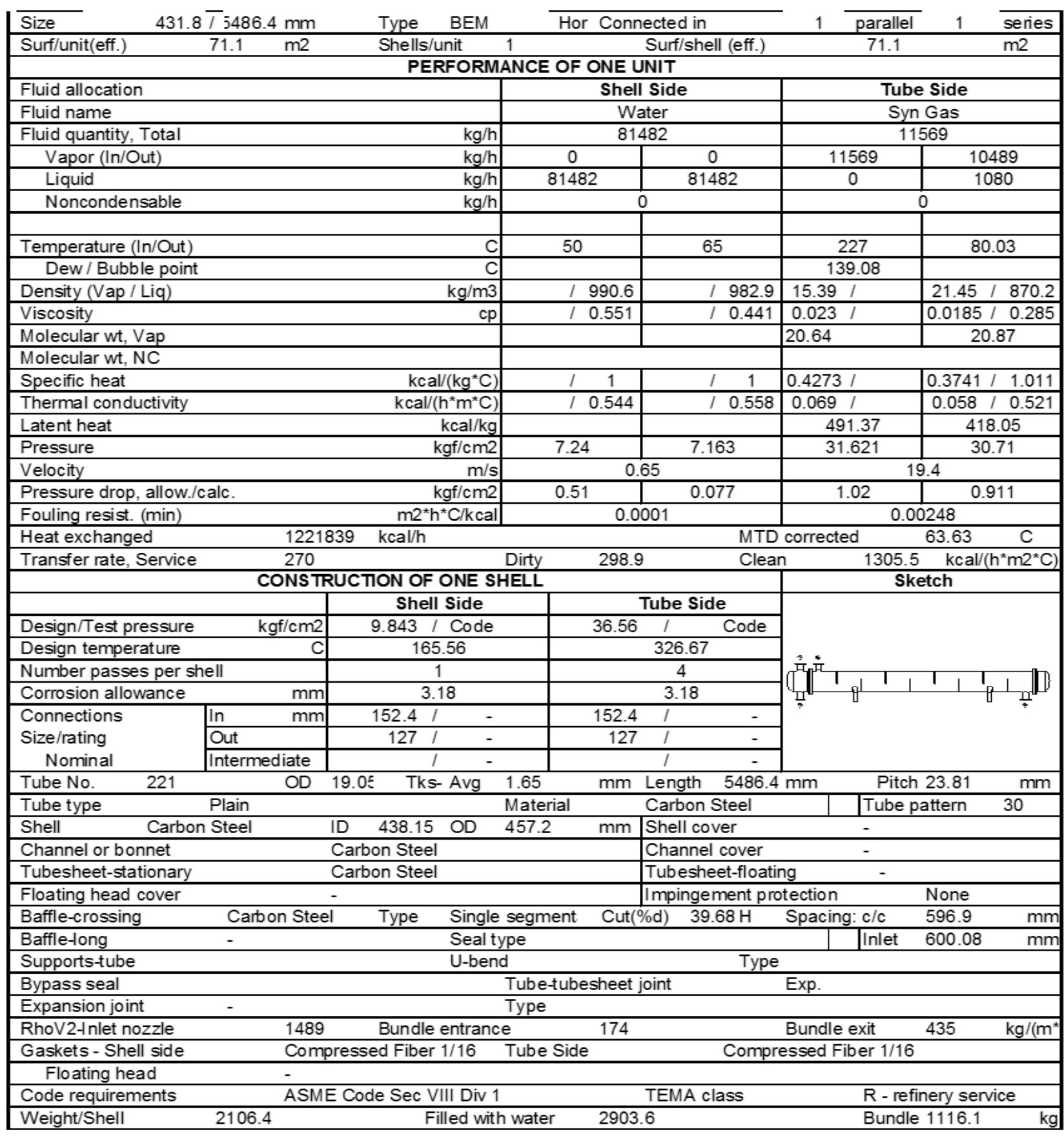

Fig. 20. Designing for heat exchanger 1 


\subsubsection{Heat exchanger 2 (Demin water cooler)}

Hot fluid in $=149^{\circ} \mathrm{F}$ and Hot fluid out $=122^{\circ} \mathrm{F}$; Cold fluid in $=91.4^{\circ} \mathrm{F}$ and Cold fluid out $=104^{\circ} \mathrm{F}$; Flow of hot fluid $=43653.1 \mathrm{lb} / \mathrm{hr} ; \mathrm{CP}$ water $=1$, Table 16 shows the demin water cooler properties for shell and tube sides.

Table 16

Heat exchange 2 (Demin water cooler)

\begin{tabular}{ll}
\hline Shell Side & Tube side \\
\hline ID $=15.25$ inch & Number $=160 ;$ Length $=8 \mathrm{ft}$ \\
Baffle space =6 & OD $=0.75$ inch; BWG=16; Pitch $=0.9375$ inch \\
Passes=1 & Passes =2 \\
\hline
\end{tabular}

Heat Balance; Distilled Water $(Q)=1178634 \mathrm{btu} / \mathrm{hr}$; Raw water $(\mathrm{m})=93542.36 \mathrm{lb} / \mathrm{hr}$. Table 17 shows the $\Delta \mathrm{T}$ (hot and cold fluid difference).

\section{Table 17}

Hot and cold fluid difference

\begin{tabular}{llll}
\hline & Hot Fluid & Cold Fluid & Differences \\
\hline High Temperature & 149 & 104 & 45 \\
Lower Temperature & 122 & 91.4 & 30.6 \\
Differences & 27 & 12.6 & 14.4 \\
\hline
\end{tabular}

$\mathrm{LMTD}=18.89416514^{\circ} \mathrm{F}, \mathrm{R}=2.142857143, \mathrm{~S}=0.21875, \mathrm{Ft}=0.97$ and $\Delta \mathrm{T}=18.32734018^{\circ} \mathrm{F}$.

Te and te; the viscosities will vary too little to require correction flow in the tubes to prevent corrosion of the shell [25]. Table 18 shows the hot and cold fluid for shell and tube side water.

Table 18

Hot and cold fluid for shell and tube side water

\begin{tabular}{|c|c|c|c|c|c|}
\hline \multicolumn{3}{|c|}{ Hot fluid: shell side, distilled water } & \multicolumn{3}{|c|}{ Cold fluid: tube side, water } \\
\hline \multirow[t]{2}{*}{ 4') } & \multirow[t]{2}{*}{ as } & \multirow[t]{2}{*}{$I D^{*} C^{\prime} B / 144 P t=0.127083333$} & \multirow{2}{*}{ 4) } & at' & 0.302 \\
\hline & & & & at & Nta't $/ 144 n=0.167778$ \\
\hline \multirow[t]{3}{*}{ 5') } & \multirow[t]{2}{*}{$\mathrm{Ga}$} & \multirow[t]{2}{*}{$\mathrm{W} / \mathrm{as}=343499.8033$} & \multirow{2}{*}{ 5) } & Gt & w/at $=557537.2$ \\
\hline & & & & $\mathrm{V}$ & 2.484303 Fps \\
\hline & At Ta & $135.5^{\circ} \mathrm{F}$ & \multirow{4}{*}{ 6) } & At ta & $97.7^{\circ} \mathrm{F}$ \\
\hline \multirow{3}{*}{ 6') } & meu & 1.164988 & & meu & 1.687466 \\
\hline & $\mathrm{De}$ & 0.045833333 & & $\mathrm{Dt}$ & 0.054167 \\
\hline & $\operatorname{Re}$ & $\mathrm{DeGa} / \mathrm{meu}=13514.07996$ & & $\operatorname{Re}$ & DtGt $/$ meu $=17896.62$ \\
\hline \multirow[t]{2}{*}{ 7') } & jh & 76 & & & \\
\hline & At Ta & $135.5^{\circ} \mathrm{F}$ & & & \\
\hline \multirow[t]{2}{*}{ 8') } & $\mathrm{K}$ & 0.378 & & & \\
\hline & & $(\mathrm{cpmeu} / \mathrm{k})^{\wedge}(1 / 3)=1.455268796$ & & & \\
\hline 9') & ho & $\mathrm{jh} *(\mathrm{~K} / \mathrm{De})^{*}(\mathrm{cpmeu} / \mathrm{k})^{\wedge}(1 / 3)^{*} 1=912.1518978$ & 9) & hi & 675 \\
\hline $\left.10^{\prime}\right)$ & 11') and & $\left.12^{\prime}\right)$ viscosity correction is unnecessary & 10) & hio & hi*ID/OD = 558 \\
\hline \multirow[t]{2}{*}{ 13) } & Clean & verall coefficient & & & \\
\hline & Uc & hio*ho/(hio+ho) $=346.2096398$ & & & \\
\hline \multirow[t]{4}{*}{ 14) } & Desigr & overall coefficient & & & \\
\hline & & $a^{\prime \prime}$ & \multicolumn{3}{|c|}{0.1963} \\
\hline & & total surface $A$ & \multicolumn{3}{|c|}{$251.264 \mathrm{ft}^{2}=23.34 \mathrm{~m}^{2}$} \\
\hline & & Ud & \multicolumn{3}{|c|}{$\mathrm{Q} / \mathrm{A} \Delta \mathrm{T}=255.94647$} \\
\hline 15) & \multicolumn{2}{|c|}{ Dirt Factor Rd $=(U c-U d) /(U c U d)=0.001018644$} & & & \\
\hline
\end{tabular}




\section{Summary $=912.1518978$}

$\mathrm{H}$ outside $=558, \mathrm{Uc}=346.2096, \mathrm{Ud}=255.9465$, Rd calculated $=0.001019$ and $\mathrm{Rd}$ required $=0.001$

Table 19 shows the pressure drop in heat exchanger.

Table 19

Pressure drop in heat exchanger

\begin{tabular}{|c|c|c|c|c|c|}
\hline \multicolumn{6}{|c|}{ Pressure Drop } \\
\hline \multirow{2}{*}{ 1') } & For Rea & 13514.0799 & \multirow{2}{*}{ 1) } & \multirow{2}{*}{$\begin{array}{l}\text { For Ret } \\
f\end{array}$} & 17896.62 \\
\hline & $\mathrm{F}$ & 0.00195 & & & 0.000195 \\
\hline \multirow{3}{*}{$\left.2^{\prime}\right)$} & Number & $-1=12 \mathrm{~L} / \mathrm{B}$ & \multirow{3}{*}{ 2) } & \multirow{3}{*}{$\Delta \mathrm{Pt}$} & $f^{*} G t^{\wedge} 2^{*} \operatorname{Ln}$ \\
\hline & 16 & & & & $5.22 * 10^{\wedge} 10^{*}$ Dsfit \\
\hline & $\begin{array}{l}\text { D } \\
\text { Ds }\end{array}$ & 1.270833333 & & & $=0.343004$ Psi \\
\hline \multirow{4}{*}{ 3') } & \multirow{4}{*}{$\Delta \mathrm{P}$} & & & Gt & 557537.2 \\
\hline & & $f * G^{\wedge} 2 * D a(N+1)$ & 3) & $V^{\wedge} 2 / 2 g^{\prime}$ & 0.041 \\
\hline & & $5.22 * 10^{\wedge} 10^{*}$ DssFls & & $\Delta \mathrm{Pr}$ & $(4 \mathrm{~N} / \mathrm{s})\left(\mathrm{V}^{\wedge} 2 / 2 \mathrm{~g}^{\prime}\right)=2.624 \mathrm{Psi}$ \\
\hline & & $=1.95543881 \mathrm{PSI}$ & 4) & $\Delta \mathrm{P}$ & $\Delta \mathrm{Pt}+\Delta \mathrm{Pr}=2.967004 \mathrm{Psi}$ \\
\hline \multicolumn{2}{|c|}{ Allowable $\Delta \mathrm{P}$} & 10 Psi & \multicolumn{2}{|c|}{ Allowable $\Delta \mathrm{P}$} & 10 Psi \\
\hline
\end{tabular}

\subsubsection{Cooling tower calculation}

Table 20 and Figure 21 shows the cooling tower calculations. Base Area $=16 \mathrm{~m}^{2} ; \lambda \mathrm{H}_{2} \mathrm{O}=2495 \mathrm{KJ} / \mathrm{Kg}$; $\mathrm{Cp}$ air $=1.003 \mathrm{KJ} / \mathrm{Kg} \mathrm{K} ; \mathrm{Cp} \mathrm{H}_{2} \mathrm{O}=2.006 \mathrm{KJ} / \mathrm{Kg} \mathrm{K}$; Tin $\mathrm{H}_{2} \mathrm{O}=316.15 \mathrm{~K}$; Tout $\mathrm{H}_{2} \mathrm{O}=306.15 \mathrm{~K}$; Tin Air=306 K; Air Flow $=1.75279 \mathrm{~m}^{3} / \mathrm{m}^{2} \mathrm{sec} ; \mathrm{m} \mathrm{H}_{2} \mathrm{O}=0.67415 \mathrm{Kg} / \mathrm{m}^{2}$.sec; $\mathrm{hDa}=0.2 \mathrm{sec}^{-1}$ (Assumed); $\mathrm{RH}=37.7 \%$.

From RC; At $306 \mathrm{~K}$ and $37.7 \% ; \mathrm{H}=0.013 \mathrm{Kg} / \mathrm{Kg} ; \mathrm{HG}_{1}=66.3984857 \mathrm{KJ} / \mathrm{Kg}$; In inlet air water vapour $=0.020944444 \mathrm{Kmol} / \mathrm{Kmol}$ dry air; Dry air flow $=1.716078787 \mathrm{~m}^{3} / \mathrm{m}^{2} \mathrm{sec}$; Density of air at $306.15 \mathrm{~K}=1.15502451 \mathrm{Kg} / \mathrm{m}^{3} \mathrm{~m}$; dry air=1.98211306 Kg/m² sec; Slope of operating line=1.421688327.

Table 20

Cooling tower calculations

\begin{tabular}{llllll}
\hline $\mathrm{H}$ & $\mathrm{HG}$ & $\mathrm{T}$ & $\mathrm{HF}$ & $\mathrm{HF}-\mathrm{HG}$ & $1 /(\mathrm{HF}-\mathrm{HG})$ \\
\hline 0.079 & 66.3984857 & 306.15 & 235.6078631 & 169.2094 & 0.005909838 \\
0.08 & 70 & 323.6 & 258.472088 & 188.4721 & 0.005305825 \\
0.107 & 110 & 327 & 332.717668 & 222.7177 & 0.00448999 \\
0.131 & 150 & 331 & 400.260588 & 250.2606 & 0.003995835 \\
0.151 & 190 & 334 & 456.405266 & 266.4053 & 0.00375368 \\
0.1681 & 230 & 337 & 505.1828504 & 275.1829 & 0.003633947 \\
0.1876 & 270 & 340 & 560.4768152 & 290.4768 & 0.003442616 \\
0.2071 & 310 & 344 & 617.4239246 & 307.4239 & 0.003252837 \\
0.2266 & 350 & 348 & 674.68397 & 324.684 & 0.003079918 \\
\hline
\end{tabular}

Solving Integration $=\int \mathrm{dHG} /(\mathrm{HF}-\mathrm{HG})$

Equation $=\mathrm{y}=0.0203 \mathrm{x}^{\wedge}-0.32$

$U L=310, L L=66.3984857$ and $d H G=2.436015143$

Answer of integration $=0.984396556$

Height $=8.446510243 \mathrm{~m}$

Two Phase Seperator: Vapour flow $=21204 \mathrm{lb} / \mathrm{hr}$, Liquid flow=2181.6 lb/hr, Total flow=23385.6 lb $/ \mathrm{hr}$, Temperature $=176{ }^{\circ} \mathrm{F}$, Pressure $=420.5 \mathrm{psig}$, Density of gas $=1.34 \mathrm{lb} / \mathrm{ft}^{3}$, Density of liquid=54.37 lb/ $/ \mathrm{ft}^{3}$, Gas molecular weight $=20.64$, Liquid molecular weight $=20.87$

Terminal velocity: $\mathrm{Vt}=0.315 \times \mathrm{V}(\mathrm{pl}-\mathrm{pg} / \mathrm{pg})=1.982 \mathrm{ft} / \mathrm{s}$ 
Volumetric flow rate of gas $(Q G)=4.395522 \mathrm{ft}^{3} / \mathrm{s}$; Volumetric flow rate of liquid $(\mathrm{QL})=0.011146 \mathrm{ft}^{3} / \mathrm{s}$ Optimum diameter: $\mathrm{Dv}=\mathrm{V}(4 \times \mathrm{QG} / \mathrm{pi} * \mathrm{Vt})=1.68 \mathrm{ft}$

Dia round off to $2 \mathrm{ft}$; Allow a minimum of 3 min hold up; $V=2.01 \mathrm{ft}^{3}$

Maximum allowable Gas mass velocity necessary for particles of size Dp to drop or settle out of gas $\mathrm{Gm}=\mathrm{C} V \mathrm{pg}(\mathrm{pl}-\mathrm{pg})=6743.777 \mathrm{lb} / \mathrm{ft}^{2} . \mathrm{hr}=1.873271 \mathrm{lb} / \mathrm{ft}^{2} . \mathrm{s}$

Liquid depth; $\mathrm{Hv}=\mathrm{V} /(\mathrm{PIxDv} 2 / 4)=0.91 \mathrm{ft}$

A two phase separator of schedule $80 "$, having a dia of $2 \mathrm{ft}$ and height of $5 \mathrm{ft}$ is selected.

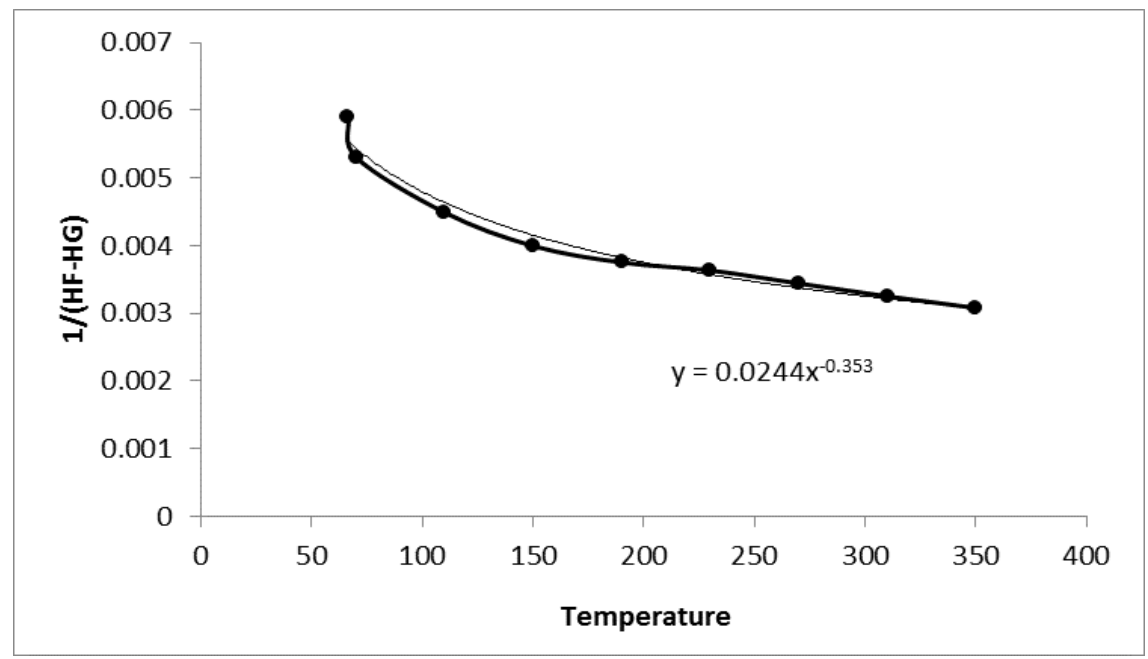

Fig. 21. Temperature versus $1 /(\mathrm{HF}-\mathrm{HG})$

\section{Conclusions}

Today, significant expenses of oil and gas and vulnerabilities about political steadiness in the greater part of oil delivering nations, have re-established interest for a wide range of fuel. A restored interest for coal gasification is in this manner not surprising. Moreover, hydrogen is presently a greeting side-effect in light of the present interest for on the other hand fuelled vehicles. UCG is possibly the most significant clean coal innovation of things to come with overall application. Eventually, it could fill in for profound digging coal for power generation use. Using improved UCG innovation to gasify thin, deep and low grade coal seams could immensely build the measure of consumable reserves. The coal could be changed over to gas for an assortment of employments and discharges of nitrous oxides, sulphur and mercury could be significantly decreased. UCG could increment recoverable coal holds around 300 to 400 percent. One more advantage of UCG is that hydrogen represents almost a large portion of the total gas item which can be isolated and effectively utilized as feed-stock for the Chemical Industry. Nations are going to UCG to completely use their coal assets in a monetarily suitable and ecologically adequate manner. Utilizing UCG innovation even without a carbon-catch and-sequestration plan could likewise be qualified for carbon credits.

\section{Acknowledgement}

The authors would like to acknowledge the Department of Chemical Engineering and Department of Polymer and Petrochemical Engineering, NED University of Engineering \& Technology, Karachi, Pakistan for supporting in this research work. 


\section{References}

[1] Chaudhry, Afraz Mehmood, Ali Arshad Uppal, Yazan M. Alsmadi, Aamer Iqbal Bhatti, and Vadim I. Utkin. "Robust multi-objective control design for underground coal gasification energy conversion process." International Journal of Control (2018): 1-8.

https://doi.org/10.1080/00207179.2018.1516893

[2] Li, Huaizhan, Nanshan Zheng, Guangli Guo, and Yu Chen. "Control measures for reduction of arsenic and cadmium contamination during underground coal gasification without shaft." Journal of Cleaner Production 219 (2019): 960 70.

https://doi.org/10.1016/i.jclepro.2019.02.154

[3] Perkins, Greg, Ernest du Toit, Greg Cochrane, and Grant Bollaert. "Overview of underground coal gasification operations at Chinchilla, Australia." Energy Sources, Part A: Recovery, Utilization, and Environmental Effects 38, no. 24 (2016): 3639-46.

https://doi.org/10.1080/15567036.2016.1188184

[4] Uppal, Ali Arshad, Saif Siddique Butt, Qudrat Khan, and Harald Aschemann. "Robust tracking of the heating value in an underground coal gasification process using dynamic integral sliding mode control and a gain-scheduled modified Utkin observer." Journal of Process Control 73 (2019): 113-22.

https://doi.org/10.1016/j.jprocont.2018.11.005

[5] Javed, Syed Bilal, Ali Arshad Uppal, Aamer Iqbal Bhatti, and Raza Samar. "Prediction and parametric analysis of cavity growth for the underground coal gasification project Thar." Energy 172 (2019): 1277-90.

https://doi.org/10.1016/j.energy.2019.02.005

[6] Doucet, Denis, Greg Perkins, Andreas Ulbrich, and Ernest du Toit. "Production of power using underground coal gasification." Energy Sources, Part A: Recovery, Utilization, and Environmental Effects 38, no. 24 (2016): 3653-60. https://doi.org/10.1080/15567036.2016.1188183

[7] Su, Fa-qiang, Akihiro Hamanaka, Ken-ichi Itakura, Wenyan Zhang, Gota Deguchi, Kohki Sato, Kazuhiro Takahashi, and Jun-ichi Kodama. "Monitoring and evaluation of simulated underground coal gasification in an ex-situ experimental artificial coal seam system." Applied Energy 223 (2018): 82-92.

https://doi.org/10.1016/i.apenergy.2018.04.045

[8] Samdani, Ganesh, Preeti Aghalayam, Anuradda Ganesh, and Sanjay Mahajani. "A process model for underground coal gasification - Part-III: Parametric studies and UCG process performance." Fuel 234 (2018): 392-405. https://doi.org/10.1016/i.fuel.2018.07.011

[9] Yang, Dongmin, Nikolaos Koukouzas, Michael Green, and Yong Sheng. "Recent development on underground coal gasification and subsequent CO 2 storage." Journal of the Energy Institute 89, no. 4 (2016): 469-84.

https://doi.org/10.1016/i.joei.2015.05.004

[10] Fallahi, Y., A. A. Aydın, M. Gür, and H. Okutan. "Investigation of the pollution risk of residues from a laboratoryscale underground coal gasification of Malkara (Turkey) lignite." International Journal of Environmental Science and Technology 16, no. 2 (2018): 1093-102. https://doi.org/10.1007/s13762-018-1746-3

[11] Xin, Lin, Zuo-tang Wang, Gang Wang, Wen Nie, Gang Zhou, Wei-min Cheng, and Jun Xie. "Technological aspects for underground coal gasification in steeply inclined thin coal seams at Zhongliangshan coal mine in China." Fuel 191 (2017): 486-94. https://doi.org/10.1016/i.fuel.2016.11.102

[12] Su, Fa-qiang, Ken-ichi Itakura, Gota Deguchi, and Koutarou Ohga. "Monitoring of coal fracturing in underground coal gasification by acoustic emission techniques." Applied Energy 189 (2017): 142-56. https://doi.org/10.1016/i.apenergy.2016.11.082

[13] Lu, Haifeng, Xiaolei Guo, Peng Li, Kai Liu, and Xin Gong. "Design optimization of a venturi tube geometry in densephase pneumatic conveying of pulverized coal for entrained-flow gasification." Chemical Engineering Research and Design 120 (2017): 208-17.

https://doi.org/10.1016/j.cherd.2017.02.020

[14] Nakaten, Natalie, and Thomas Kempka. "Techno-Economic Comparison of Onshore and Offshore Underground Coal Gasification End-Product Competitiveness." Energies 12, no. 17 (2019): 3252. https://doi.org/10.3390/en12173252

[15] Nakaten, Natalie Christine, and Thomas Kempka. "Radial-symmetric well design to optimize coal yield and maintain required safety pillar width in offshore underground coal gasification." Energy Procedia 125, no. 1 (2017): 27-33. https://doi.org/10.1016/i.egypro.2017.08.044

[16] Perkins, Greg. "Underground coal gasification - Part I: Field demonstrations and process performance." Progress in Energy and Combustion Science 67 (2018): 158-87. 
https://doi.org/10.1016/j.pecs.2018.02.004

[17] Uppal, Ali A., Yazan M. Alsmadi, Vadim I. Utkin, Aamer I. Bhatti, and Shahid A. Khan. "Sliding Mode Control of Underground Coal Gasification Energy Conversion Process." IEEE Transcations on control systems Technology 26, no. 2 (2018): 587-98. https://doi.org/10.1109/TCST.2017.2692718

[18] Li, Huaizhan, Guangli Guo, and Nanshan Zheng. "Influence of coal types on overlying strata movement and deformation in underground coal gasification without shaft and prediction method of surface subsidence." Process Safety and Environmental Protection 120 (2018): 302-12.

https://doi.org/10.1016/i.psep.2018.09.023

[19] Pei, Peng, Junior Nasah, Jaroslav Solc, Scott F. Korom, Daniel Laudal, and Kirtipal Barse. "Investigation of the feasibility of underground coal gasification in North Dakota, United States." Energy Conversion and Management 113 (2016): 95-103. https://doi.org/10.1016/j.enconman.2016.01.053

[20] Yilmaz, Fatih, Murat Ozturk, and Resat Selbas. "Design and thermodynamic analysis of coal-gasification assisted multigeneration system with hydrogen production and liquefaction." Energy Conversion and Management 186 (2019): 229-40.

https://doi.org/10.1016/i.enconman.2019.02.053

[21] Brand, Johan F., Johan C. Van Dyk, and Frans B. Waanders. "Economic overview of a two-agent process for underground coal gasification with Fischer-Tropsch-based poly-generation." Clean Energy 3, no. 1 (2019): 34-46. https://doi.org/10.1093/ce/zky023

[22] Falshtynskyi, Volodymyr, Roman Dychkovskyi, Pavlo Saik, Vasyl Lozynskyi, Victor Sulaiev, and Edgar Cáceres Cabana. "The Concept of Mining Enterprises Progress on the Basis of Underground Coal Gasification Method Characteristic." Solid State Phenomena 291 (2019): 137-47. https://doi.org/10.4028/www.scientific.net/SSP.291.137

[23] Jowkar, Amin, Farhang Sereshki, and Mehdi Najafi. "A new model for evaluation of cavity shape and volume during Underground Coal Gasification process." Energy 148 (2018): 756-65. https://doi.org/10.1016/i.energy.2018.01.188

[24] Robert, C. G., A. Ayob, MF Mohammad Zaki, MZA Mohd Zahid, and L. Ee Von. "Polyvinyl-Alcohol-Modified Coal-Ash Mixtures for Productive Geotechnical Application." Journal of Advanced Research in Materials Science 10, no.1 (2015): 12-25.

[25] Lubis, Hamzah. "Renewable Energy of Rice Husk for Reducing Fossil Energy in Indonesia." Journal of Advanced Research in Applied Sciences and Engineering Technology 11, no.1 (2018): 17-22. 